In cooperation with the Edwards Aquifer Authority

Streamflow Conditions in the Guadalupe River Basin, South-Central Texas, Water Years 1987-2006-An Assessment of Streamflow Gains and Losses and Relative Contribution of Major Springs to Streamflow

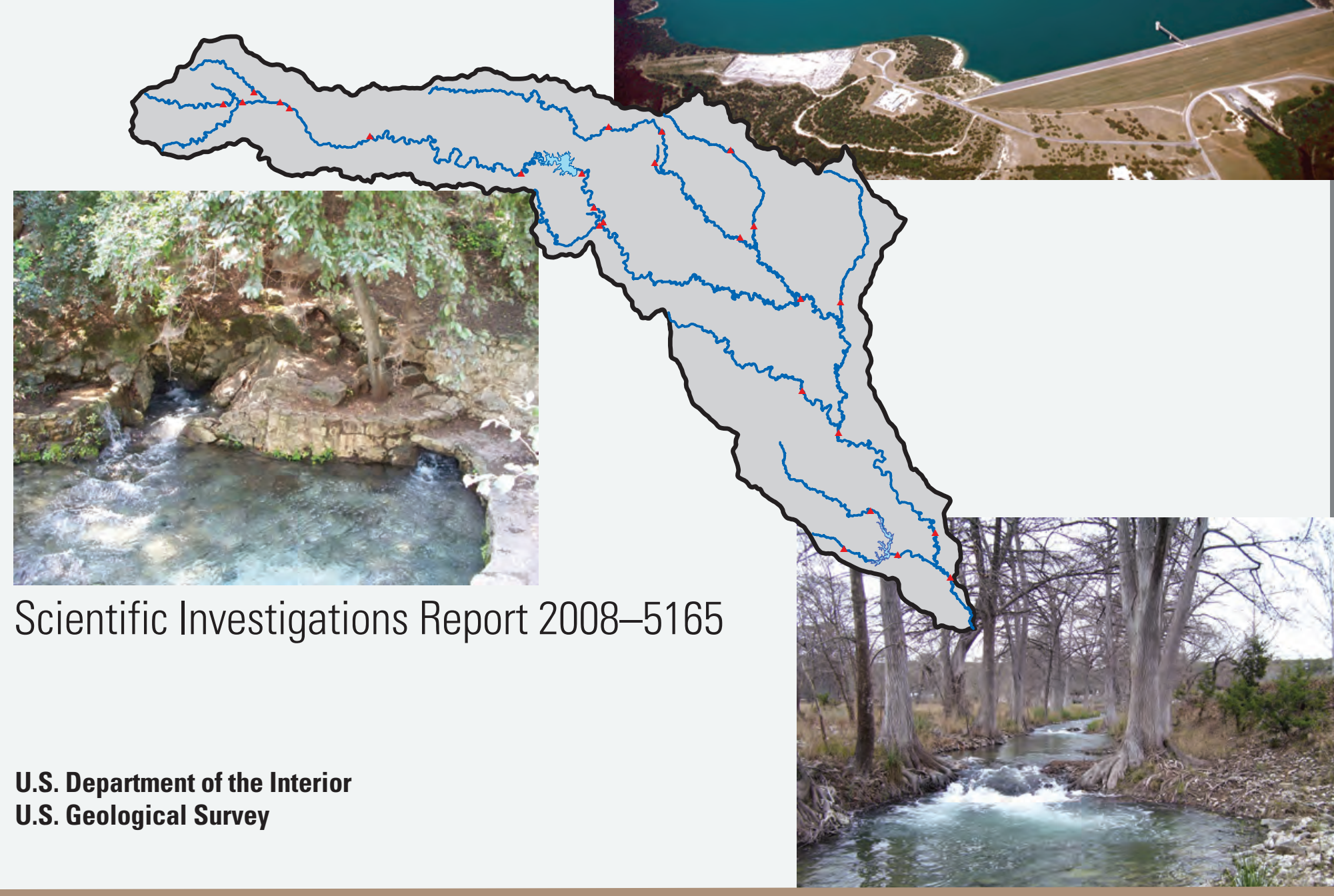




\section{Cover:}

Photographs

Top, Canyon Dam and Lake near New Braunfels, Texas (photograph from U.S. Army Corps of Engineers, Fort Worth District, http://www.swf-wc.usace.army.mil/canyon/).

Bottom, Guadalupe River near Hunt, Texas December, 17, 2007 (photograph by Brian Petri, U.S.

Geological Survey).

Left, Major spring orifices of Comal Springs in New Braunfels, Texas, January 26, 2007.

Map, Guadalupe River Basin, South-Central Texas, showing location of U.S. Geological Survey gaging stations. 


\section{Streamflow Conditions in the Guadalupe River Basin, South-Central Texas, Water Years 1987-2006-An Assessment of Streamflow Gains and Losses and Relative Contribution of Major Springs to Streamflow}

By Darwin J. Ockerman and Richard N. Slattery

In cooperation with the Edwards Aquifer Authority

Scientific Investigations Report 2008-5165 


\section{U.S. Department of the Interior DIRK KEMPTHORNE, Secretary}

\section{U.S. Geological Survey \\ Mark D. Myers, Director}

\section{U.S. Geological Survey, Reston, Virginia: 2008}

For product and ordering information:

World Wide Web: http://www.usgs.gov/pubprod

Telephone: 1-888-ASK-USGS

For more information on the USGS — the Federal source for science about the Earth, its natural and living resources, natural hazards, and the environment:

World Wide Web: http://www.usgs.gov

Telephone: 1-888-ASK-USGS

Any use of trade, product, or firm names is for descriptive purposes only and does not imply endorsement by the U.S. Government.

Although this report is in the public domain, permission must be secured from the individual copyright owners to reproduce any copyrighted materials contained within this report.

Suggested citation:

Ockerman, D.J., and Slattery, R.N., 2008, Streamflow conditions in the Guadalupe River Basin, south-central Texas, water years 1987-2006 - An assessment of streamflow gains and losses and relative contribution of major springs to streamflow: U.S. Geological Survey Scientific Investigations Report 2008-5165, 22 p. 


\section{Contents}

Abstract
Introduction .
Purpose and Scope
Description of Study Area
Streamflow Conditions
$\quad$ Streamflow Statistics of U.S. Geological Survey Gaging-Station Data
$\quad$ Reported Within-Reach Discharges and Withdrawals
$\quad$ Analyses of Streamflow Conditions for Water Years 1987-2006
Analyses of Streamflow Conditions for Selected Short-Term Periods
Summary
References

\section{Figure}

1. Map showing Guadalupe River Basin, south-central Texas, locations of U.S. Geological Survey streamflow-gaging stations, and locations of stream reaches used for analysis of streamflow conditions

\section{Tables}

1. Selected U.S. Geological Survey streamflow-gaging stations, Guadalupe River

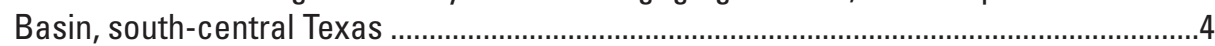

2. Stream reaches for which streamflow conditions analyzed, Guadalupe River Basin, south-central Texas

3. Daily streamflow statistics for selected U.S. Geological Survey streamflowgaging stations, Guadalupe River Basin, south-central Texas:

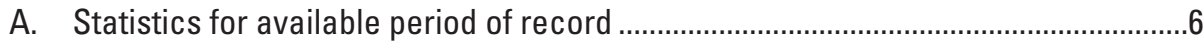

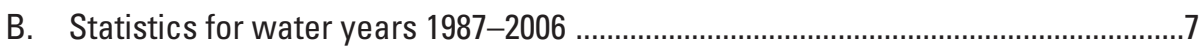

4. Summary of average streamflow conditions for 1987-2006 by stream reach, Guadalupe River Basin, south-central Texas ...........................................................10

5. Average springflows at major springs for selected short-term periods compared with long-term flow statistics, Guadalupe River Basin, south-central Texas.

6. Summary of streamflow conditions for selected short-term periods by stream reach, Guadalupe River Basin, south-central Texas

7. Comparison of contributions of Canyon Lake releases and flow from major springs to streamflow in selected stream reaches for selected short-term periods, Guadalupe River Basin, south-central Texas 


\section{Conversion Factors and Datum}

\section{Inch/Pound to SI}

\begin{tabular}{lll}
\hline \multicolumn{1}{c}{ Multiply } & By & \multicolumn{1}{c}{ To obtain } \\
\hline inch (in.) & Length & \\
foot (ft) & 25.4 & millimeter $(\mathrm{mm})$ \\
mile (mi) & 0.3048 & meter $(\mathrm{m})$ \\
\hline \multicolumn{3}{c}{ Ailometer $(\mathrm{km})$} \\
\hline square mile $\left(\mathrm{mi}^{2}\right)$ & 1.609 & \\
\hline \multicolumn{3}{c}{ Area } \\
\hline cubic foot per second $\left(\mathrm{ft}^{3} / \mathrm{s}\right)$ & 2.590 & square kilometer $\left(\mathrm{km}^{2}\right)$ \\
\hline & Flow rate & \\
\hline acre-foot $($ acre-ft) & 0.02832 & cubic meter per second $\left(\mathrm{m}^{3} / \mathrm{s}\right)$ \\
\hline
\end{tabular}

Temperature in degrees Fahrenheit $\left({ }^{\circ} \mathrm{F}\right)$ may be converted to degrees Celsius $\left({ }^{\circ} \mathrm{C}\right)$ as follows: ${ }^{\circ} \mathrm{C}=\left({ }^{\circ} \mathrm{F}-32\right) / 1.8$

\section{Datum}

Horizontal coordinate information is referenced to the North American Datum of 1983 (NAD 83). 


\title{
Streamflow Conditions in the Guadalupe River Basin, South-Central Texas, Water Years 1987-2006-An Assessment of Streamflow Gains and Losses and Relative Contribution of Major Springs to Streamflow
}

\author{
By Darwin J. Ockerman and Richard N. Slattery
}

\begin{abstract}
The U.S. Geological Survey, in cooperation with the Edwards Aquifer Authority, assessed available streamflow data in the Guadalupe River Basin to determine streamflow gains and losses and the relative contribution of flow from major springs-Comal Springs, San Marcos Springs, and Hueco Springs - to streamflow in reaches of the Guadalupe River and its tributaries. The assessment is based primarily on long-term (1987-2006) and short-term (January 1999, August 1999, August 2000, and August 2006) streamflow conditions. For each analysis period, the ratio of flow from the major springs (measured at the spring source) to the sum of inflows (measured at the source of inflow to the river system) is computed for reaches of the Comal River and San Marcos River that include springflows from major springs, and for Guadalupe River reaches downstream from Canyon Dam. The ratio of springflow to the sum of inflows to the reach is an estimate of the contribution of flows from major springs to streamflow. For 1987-2006, the ratio of springflow from the major springs to the sum of inflows for the most upstream reach that includes inflow from all three major springs, Guadalupe River-above Comal River to Gonzales, is 27 percent. At the lowermost downstream reach, Guadalupe River-Bloomington to the San Antonio River, the percentage of the sum of inflows attributed to springflow is 18 percent. At that lowermost reach, the ratio of Canyon Lake releases to the sum of inflows was 20 percent. For the short-term periods August 2000 and August 2006 (periods of relatively low flow), springflow in the reach Guadalupe River-above Comal River to Gonzales accounted for 77 and 78 percent, respectively, of the sum of inflows in that reach. At the lowermost reach Guadalupe River-Bloomington to San Antonio River, springflow was 52 and 53 percent of the sum of inflows, respectively, during August 2000 and August 2006 (compared with 18 percent during 1987-2006); and during August 2000 and August 2006, the ratios of Canyon Lake releases to the sum of inflows were less than 10 percent (compared with 20 percent during 1987-2006).
\end{abstract}

\section{Introduction}

The Guadalupe River and its tributaries in south-central Texas are a vital source of water for Kerrville, New Braunfels, Victoria, and other towns; and the streams supply water for farms, ranches, and industry. The Guadalupe River also is a popular stream for tubing, canoeing, fishing, and other recreational activities. The Guadalupe River Basin (GRB) includes important springs that sustain streamflow and provide habitat for several endangered and threatened species.

Streamflow conditions ${ }^{1}$ in the GRB are affected by springflow (spring discharge), rainfall-runoff processes, pointsource discharges, withdrawals for water supply, reservoir operations, evapotranspiration, and losses to aquifer recharge. A better understanding of how these factors, or changes in these factors, affect streamflow conditions can help resource managers design watershed-management and operation strategies to optimize use of available water resources. The U.S. Geological Survey (USGS), in cooperation with the Edwards Aquifer Authority, compiled and analyzed data on streamflow conditions to assess streamflow gains and losses and the relative contribution of flow of major springs to streamflow in the GRB.

\section{Purpose and Scope}

The purpose of this report is to describe streamflow conditions in the GRB - that is, water-budget components of stream reaches-that constitute streamflow gains and losses and the relative contribution of flow of from major springs to streamflow in selected reaches of the Guadalupe River and its tributaries. The assessment of streamflow gains and losses and the relative contribution of springflow to streamflow is based primarily on long-term (20 years) and short-term (four

\footnotetext{
1 "Conditions" in the context of this report refers to water-budget components of stream reaches - upstream flow, downstream flow, and intervening gains and losses of flow including gains from major springs.
} 
1-month base-flow periods) streamflow conditions. Streamflow and springflow data used were collected at 28 streamflow-gaging stations operated by the USGS during water years 1987-2006 (October 1986 through September 2006); the 1-month base-flow periods were January 1999, August 1999, August 2000, and August 2006. Permitted, within-reach discharge (inflow to the reach) and withdrawal (outflow from the reach) data used were reported by the Texas Commission on Environmental Quality (TCEQ).

\section{Description of Study Area}

The headwaters of the Guadalupe River form in southwestern Kerr County. From there, the river flows easterly for about 250 river miles to Gonzales, then southeasterly for another 150 river miles to join the San Antonio River 11 river miles upstream from Guadalupe Bay, which is part of the San Antonio Bay system (fig. 1). The drainage area of the Guadalupe River is about 10,200 square miles including the San Antonio River watershed. The study area-the GRB upstream from the confluence of the Guadalupe and San Antonio Rivers-comprises 5,974 square miles and excludes the San Antonio River Basin. The Blanco River and San Marcos River are principal tributaries of the Guadalupe River. Two major reservoirs are in the GRB: Canyon Lake is on the Guadalupe River in Comal County, about 12 miles northwest of New Braunfels. The reservoir impounds runoff from 1,432 square miles of drainage area and has 382,000 acre-feet of authorized conservation storage (Guadalupe-Blanco River Authority, 2007a). Construction of the dam and reservoir began in 1958 and impoundment began in 1964. Coleto Creek Reservoir is on Coleto and Perdido Creeks, about 12 miles southwest of Victoria. The dam was completed in 1980 and impounds runoff from 507 square miles of drainage area. Conservation storage for the reservoir is 35,060 acre-feet (Guadalupe-Blanco River Authority, 2007b). The primary purpose of the reservoir is to provide cooling water for electric power generation.

Major population centers of the GRB include the cities of Kerrville, New Braunfels, San Marcos, Seguin, Lockhart, Gonzales, Cuero, Luling, and Victoria. The 2007 population of the basin was about 589,000 (U.S. Census Bureau, 2007). Land use in the basin is predominantly rural. Elevation in the study area ranges from about 25 feet (at station 08177520) to more than 2,000 feet above sea level in the upstream parts of the GRB.

Three major springs are in the GRB: Comal Springs, San Marcos Springs, and Hueco Springs. Comal Springs provides most of the flow in the Comal River, which joins the Guadalupe River at New Braunfels. Comal Springs, which discharges from several outlets, is the largest spring in Texas and the Southwest (Brune, 1975). Long-term average Comal Springs flow (water years 1929-2006) is 290 cubic feet per second. San Marcos Springs, also with several outlets, provides most of the base flow for the San Marcos River, which joins the Guadalupe River near Gonzales. This spring is the second largest in Texas (Brune, 1975). Long-term average flow for San Marcos Springs (water years 1957-2006) is 175 cubic feet per second. Hueco Springs is on the west side of the Guadalupe River about 3 river miles upstream from New Braunfels. Long-term average flow for Hueco Springs (water years 1944-2006) is 42 cubic feet per second. Besides these major springs east and southeast of Canyon Lake, numerous small springs in Kerr County supply much of the base flow in the headwater reaches (reaches 1-3, fig. 1) of the Guadalupe River (Heitmuller and Reece, 2003).

The climate of the study area is described as subtropical subhumid, characterized by hot summers and mild, dry winters (Larkin and Bomar, 1983). Heaviest rainfall tends to occur in spring, early summer, and fall, but can occur anytime during the year. Periods with large or small amounts of rainfall are common, resulting in recurring floods and droughts. The following meteorological statistics are from the National Weather Service station at New Braunfels (U.S. Department of Commerce, 2002): Average annual rainfall (1971-2000) is 35.74 inches per year. Rainfall greater than 0.01 inch occurs, on average, 77 days per year. The average monthly low temperatures range from 35.5 degrees Fahrenheit $\left({ }^{\circ} \mathrm{F}\right)$ in January to $70.6{ }^{\circ} \mathrm{F}$ in July. Average monthly high temperatures range from $61.7^{\circ} \mathrm{F}$ in January to $95.3^{\circ} \mathrm{F}$ in August.

\section{Streamflow Conditions}

Streamflow conditions in the GRB were analyzed by computing surface-water budgets for reaches of Guadalupe River and tributary streams. The GRB was divided into a network of 27 stream reaches, defined mainly by the locations of USGS streamflow-gaging stations. Table 1 lists the gaging stations from which data were compiled for this report, including station name and number, county, period of record, latitude and longitude, and drainage area upstream from the station. The data are in the USGS National Water Information System (NWISWeb) (U.S. Geological Survey, 2008). Table 2 lists each stream reach, including reach number and name, upstream and downstream station number, reach length, and cumulative drainage area at the downstream station. The locations of the gaging stations and stream reaches are shown in figure 1. Thirteen reaches (including the Canyon Lake reach) are on the main stem of the Guadalupe River. Fourteen reaches are on the tributaries Johnson Creek, Comal River, Blanco River, San Marcos River, Plum Creek, Peach Creek, Sandies Creek, Perdido Creek, and Coleto Creek. The farthest downstream gaging station used, 08177520 Guadalupe River near Bloomington, is a water-stage station, and discharge records are not available for the outlet of reach 26. Also, no gaging stations are at the outlets of reach 17 (lower San Marcos River), and reach 27 (Guadalupe River from Bloomington to the San Antonio River). Outflows from reaches 17, 26 (Guadalupe River-Victoria to Bloomington), and 27 are estimated as the sum of upstream gaging-station inflow, intervening runoff 


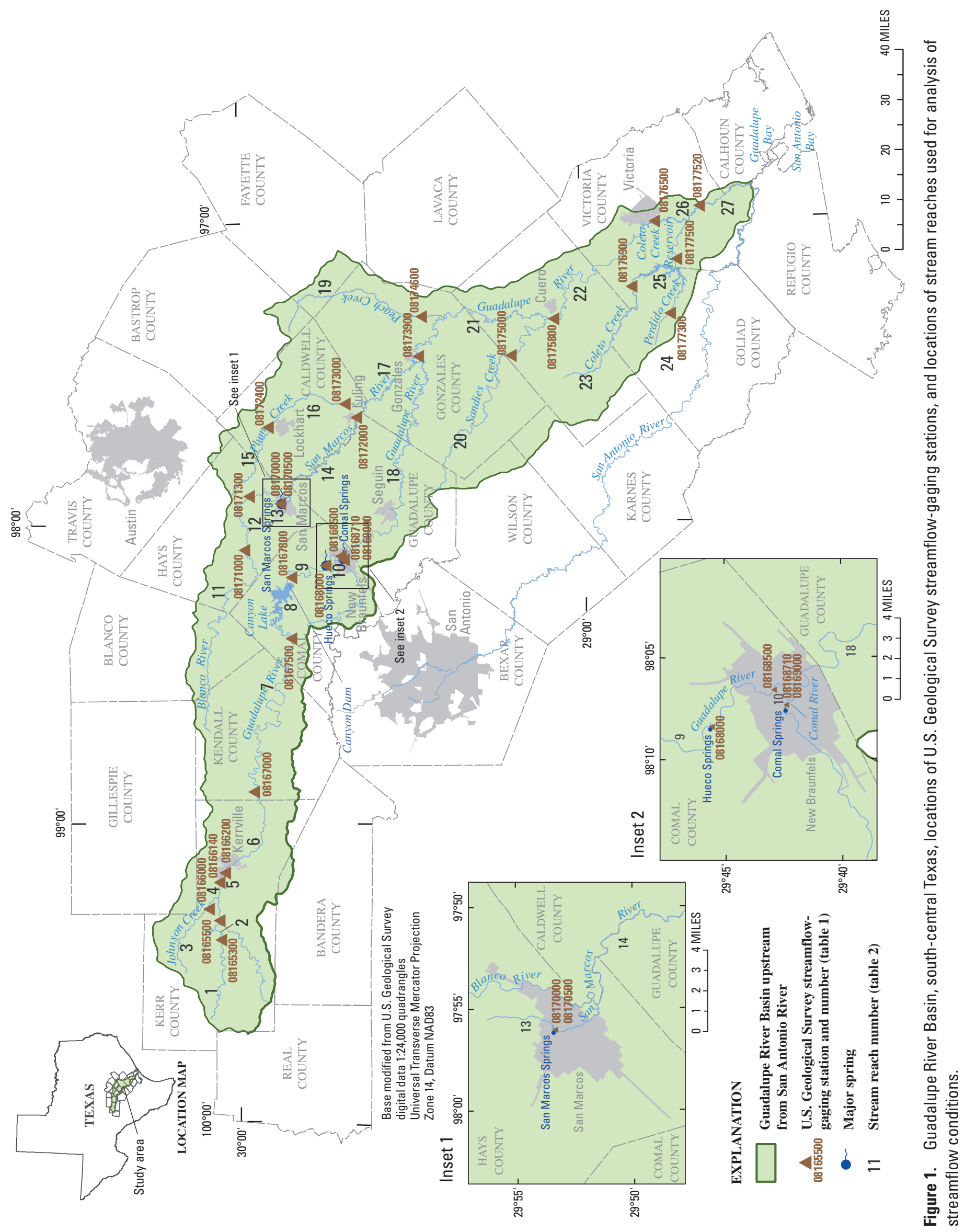


Table 1. Selected U.S. Geological Survey streamflow-gaging stations, Guadalupe River Basin, south-central Texas.

[--, not applicable]

\begin{tabular}{|c|c|c|c|c|c|c|}
\hline Station name & $\begin{array}{l}\text { Station } \\
\text { number } \\
\text { (fig. 1) }\end{array}$ & County & $\begin{array}{c}\text { Period of } \\
\text { record }^{1} \\
\text { (water years) }\end{array}$ & $\begin{array}{c}\text { Latitude } \\
\text { (degrees, } \\
\text { minutes, } \\
\text { seconds) }\end{array}$ & $\begin{array}{c}\text { Longitude } \\
\text { (degrees, } \\
\text { minutes, } \\
\text { seconds) }\end{array}$ & $\begin{array}{c}\text { Drainage } \\
\text { area } \\
\text { (square } \\
\text { miles) }\end{array}$ \\
\hline North Fork Guadalupe River near Hunt, Tex. & 08165300 & Kerr & 1968-present & 300350 & 992312 & 169 \\
\hline Guadalupe River at Hunt, Tex. & 08165500 & Kerr & 1966-present & 300411 & 991917 & 288 \\
\hline Johnson Creek near Ingram, Tex. & 08166000 & Kerr & 1942-present & 300600 & 991658 & 114 \\
\hline Guadalupe River at Kerrville, Tex. & 08166200 & Kerr & 1987-present & 300311 & 990947 & 510 \\
\hline Guadalupe River at Comfort, Tex. & 08167000 & Kendall & 1940-present & 295810 & 985333 & 839 \\
\hline Guadalupe River near Spring Branch, Tex. & 08167500 & Comal & 1923-present & 295137 & 982300 & 1,315 \\
\hline Guadalupe River at Sattler, Tex. & 08167800 & Comal & 1961-present & 295132 & 981047 & 1,436 \\
\hline Comal River at New Braunfels, Tex. & 08169000 & Comal & 1929-present & 294221 & 980720 & 130 \\
\hline San Marcos Springs at San Marcos, Tex. & 08170000 & Hays & 1957-present & 295320 & 975602 & -- \\
\hline San Marcos River at San Marcos, Tex. & 08170500 & Hays & 1994-present & 295320 & 975602 & 49 \\
\hline Blanco River at Wimberley, Tex. & 08171000 & Hays & 1929-present & 295939 & 980519 & 355 \\
\hline Blanco River near Kyle, Tex. & 08171300 & Hays & 1957-present & 295845 & 975435 & 412 \\
\hline San Marcos River at Luling, Tex. & 08172000 & Caldwell & 1940-present & 293958 & 973902 & 838 \\
\hline Plum Creek at Lockhart, Tex. & 08172400 & Caldwell & 1960-present & 295522 & 974044 & 112 \\
\hline Plum Creek near Luling, Tex. & 08173000 & Caldwell & 1931-present & 294158 & 973612 & 309 \\
\hline Coleto Creek near Schroeder, Tex. & 08176900 & Goliad & 1979-present & 285141 & 971334 & 357 \\
\hline Perdido Creek near Fannin, Tex. & 08177300 & Goliad & 1979-present & 284505 & 971901 & 28 \\
\hline Coleto Creek near Victoria, Tex. & 08177500 & Victoria & 1979-present & 284351 & 970818 & 514 \\
\hline Guadalupe River near Bloomington, Tex. & 08177520 & Victoria & 1999-present & 283943 & 965755 & 5,816 \\
\hline
\end{tabular}

${ }^{1}$ Present indicates station was active in water year 2008.

(estimated from adjacent gaged reaches using a unit-runoff approach (U.S. Environmental Protection Agency, 2008)— that is, by assuming the same discharge per unit area applies in the intervening ungaged drainage area as in adjacent gaged drainage areas), and reported within-reach discharges (inflows) minus within-reach withdrawals (outflows).

For each stream reach, streamflow data from the upstream and downstream gaging stations were compiled. Reported within-reach discharges (for example, wastewatertreatment plant discharges) and withdrawals (for example, withdrawals for irrigation or water supply) were summed.
Measured (gaged) tributary inflows or measured springflows also were accounted for. Unreported or unmeasured waterbudget components such as streambed leakage to or from a reach were not explicitly accounted for but are included in the overall reach gain (or loss), as determined by the difference in streamflow measured at the upstream and downstream gaging stations. Evaporation and rainfall components of the water budgets were computed only for the Canyon Lake reach (U.S. Army Corps of Engineers, 2007). The water-budget analyses were done for a long-term period, water years 1987-2006, and for four short-term, base-flow periods, January 1999, August 
Table 2. Stream reaches for which streamflow conditions analyzed, Guadalupe River Basin, south-central Texas.

[--, not applicable]

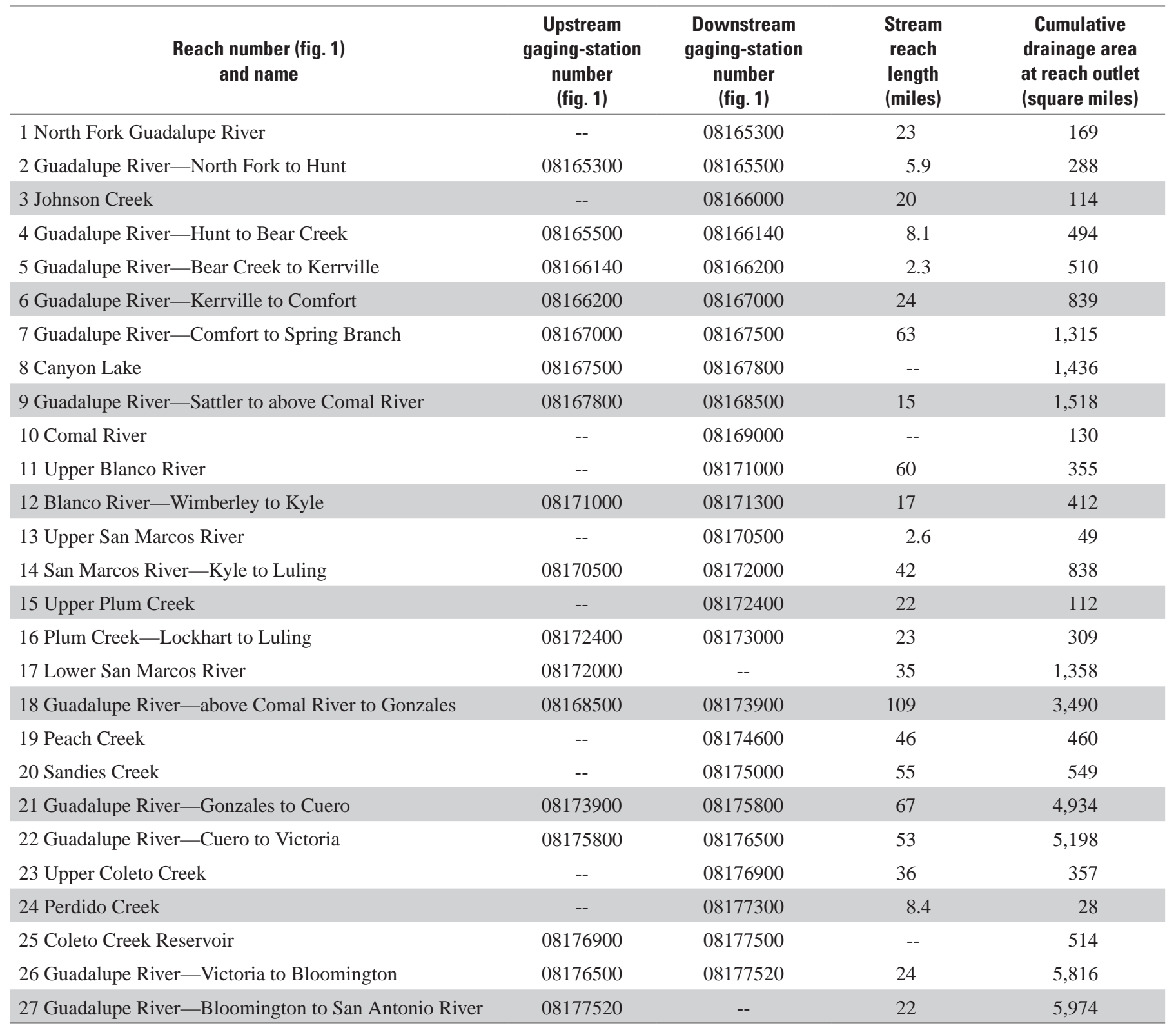

1999, August 2000, and August 2006. For each analysis period, contributions from the major springs (Comal Springs, San Marcos Springs, and Hueco Springs) to the sum of inflows are computed for various downstream locations in the Comal, San Marcos, and Guadalupe Rivers.

\section{Streamflow Statistics of U.S. Geological Survey Gaging-Station Data}

Selected daily streamflow statistics were computed for 27 active USGS gaging stations in the GRB. Statistics include average, or mean, streamflow, 20-percent exceedance stream- flow, 50-percent exceedance (median) streamflow, 80-percent exceedance streamflow, and 90-percent exceedance streamflow. The percentage exceedance streamflow is defined as the daily mean streamflow that was exceeded for the specified percentage of time during the analysis period. For example, 90-percent exceedance streamflow represents a (relatively low) daily mean streamflow that was exceeded 90 percent of the analysis period. For each gaging station, streamflow statistics were computed for two periods. First, statistics were computed for the available period of record (table 3A). Second, statistics were computed for water years 1987-2006 (table 3B). The period 1987-2006 provides a relatively long-term period of record for comparison common among most gages in the 
Table 3. Daily streamflow statistics for selected U.S. Geological Survey streamflow-gaging stations, Guadalupe River Basin, southcentral Texas.

$\left[\mathrm{ft}^{3} / \mathrm{s}\right.$, cubic feet per second; --, not applicable]

A. Statistics for available period of record

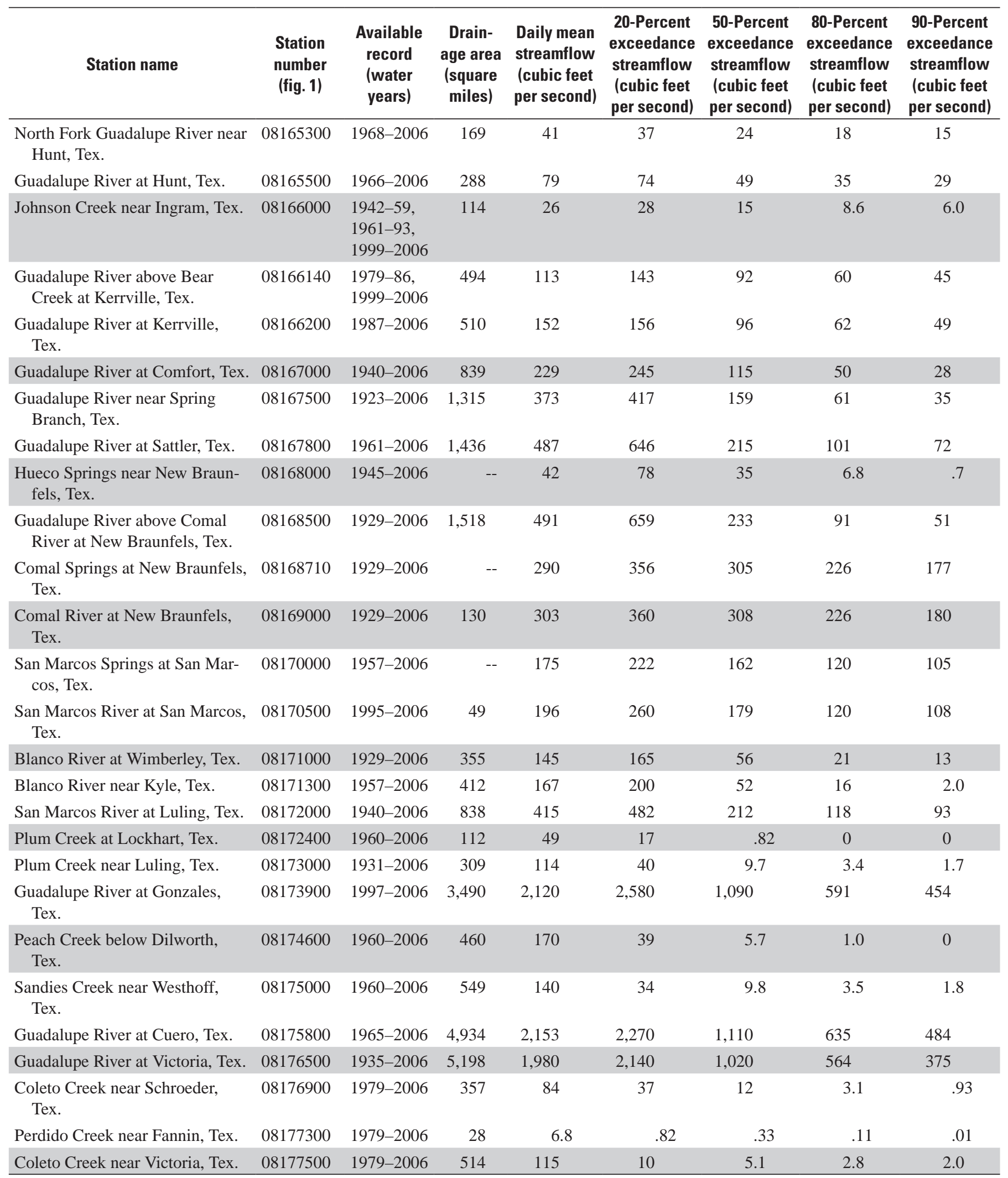


Table 3. Daily streamflow statistics for selected U.S. Geological Survey streamflow-gaging stations, Guadalupe River Basin, southcentral Texas-Continued.

B. Statistics for water years $1987-2006$

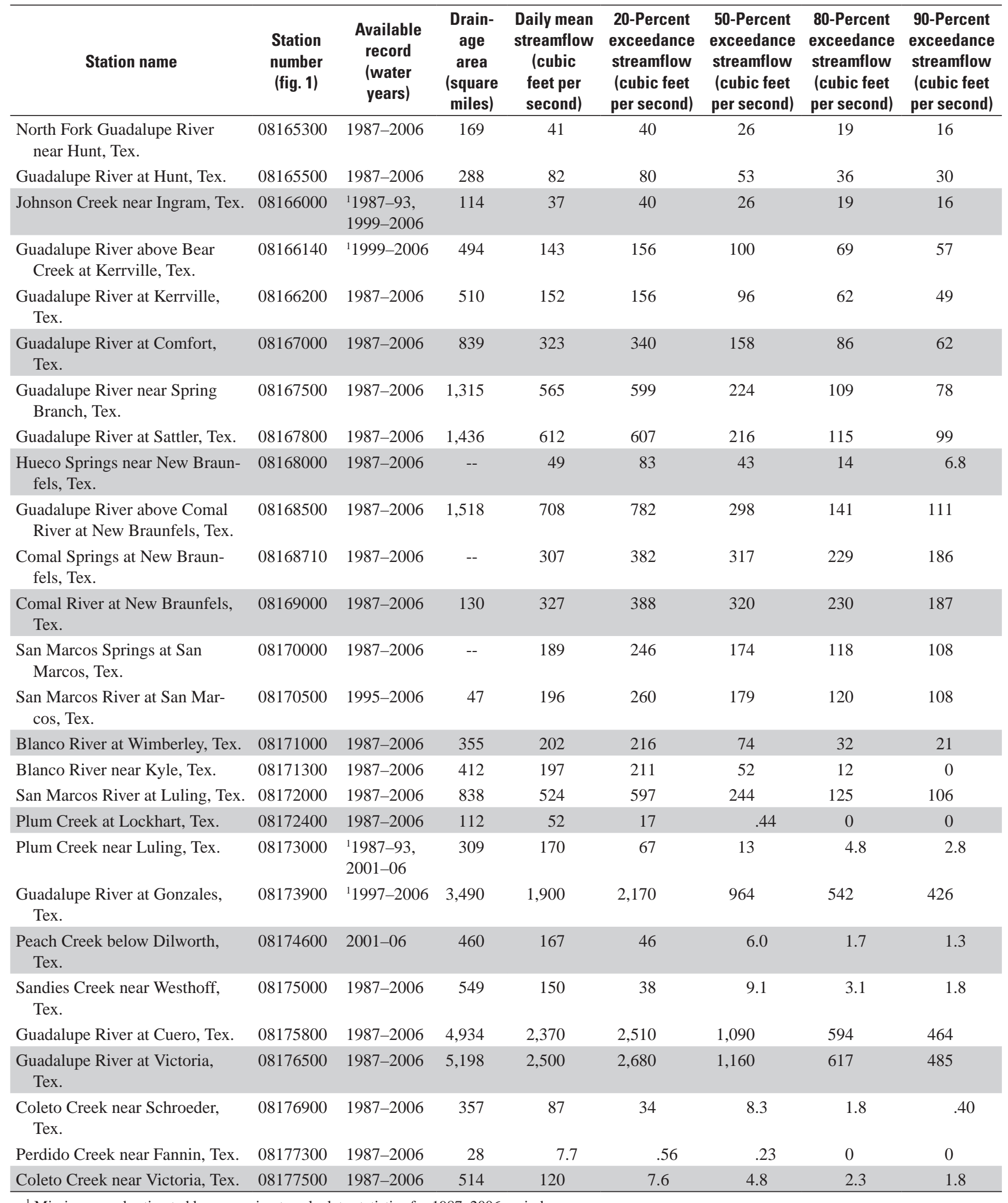

\footnotetext{
${ }^{1}$ Missing record estimated by regression to calculate statistics for 1987-2006 period.
} 
Stations with missing record during water years 1987-2006 and stations used in regressions to calculate missing record, Guadalupe River Basin, south-central Texas.

\begin{tabular}{|c|c|c|}
\hline Station with missing record & $\begin{array}{l}\text { Station or stations from which daily mean streamflow } \\
\text { or sum of daily mean streamflows obtained }\end{array}$ & $\begin{array}{l}\text { Coefficient of } \\
\text { determination }\end{array}$ \\
\hline \multirow[t]{3}{*}{ 08173900, Guadalupe River at Gonzales, Tex. } & $\begin{array}{l}\text { 08168500, Guadalupe River above Comal River at New } \\
\text { Braunfels, Tex. }\end{array}$ & .96 \\
\hline & 08169000, Comal River at New Braunfels, Tex. & \\
\hline & 08172000, San Marcos River at Luling, Tex. & \\
\hline 08166000, Johnson Creek near Ingram, Tex. & 08166200, Guadalupe River at Kerrville, Tex. & .76 \\
\hline \multirow[t]{2}{*}{$\begin{array}{l}\text { 08166140, Guadalupe River above Bear Creek at } \\
\text { Kerrville, Tex. }\end{array}$} & 08166200, Guadalupe River at Kerrville, Tex. & .95 \\
\hline & 08165500, Guadalupe River at Hunt, Tex. & \\
\hline
\end{tabular}

GRB. This period was used for long-term mean streamflow analyses. Statistics for the available period of record for each gaging station are provided for reference and for comparison with statistics for water years 1987-2006.

Daily values from USGS gaging stations used for analysis were obtained from the USGS National Water Information System (NWISWeb) (U.S. Geological Survey, 2008). These data were collected by the USGS in cooperation with Federal, State, and local agencies, including U.S. Army Corps of Engineers, Texas Water Development Board, GuadalupeBlanco River Authority, Upper Guadalupe River Authority, and Edwards Aquifer Authority. Accuracy of the streamflow records varies in time and by station. Overall, the accuracy of the records is considered "good" (excluding estimated values, 95 percent of the daily streamflows are within 10 percent of their true values) (U.S. Geological Survey, 2007).

Several stations have periods of missing record because of discontinuous station operation. Statistics in table 3A were computed using only available data. For several stations with missing record during water years 1987-2006, statistics in table 3B were computed by including estimates of missing record during the 20 -year period. These estimates were calculated by simple linear regression ${ }^{2}$ with data from nearby stations, as indicated in the table above.

The most critical missing record was for station 08173900 Guadalupe River at Gonzales. This station was installed in 1996 and therefore had no record during water years 1987-1996. The station is the endpoint for reach 18, which is the longest reach in the study area at 109 river miles. Reach 18 also includes inflow from the San Marcos River

\footnotetext{
${ }^{2}$ The model for simple linear regression is $y_{i}=b_{o}+b_{1} x_{i}$ (Helsel and Hirsch, 1992, p. 222) where $y_{i}$ is the estimate of missing streamflow on the ith day, $\mathrm{b}_{0}$ and $\mathrm{b}_{1}$ are coefficients, and $\mathrm{x}_{\mathrm{i}}$ is observed daily mean streamflow from a nearby station on the ith day, or the sum of observed daily mean streamflows from two or more stations.
}

(reach 17). Without station 08173900 , the length of reach 18 would have been increased to about 176 river miles.

For stations with periods of record beginning before approximately 1950, statistics for the water year 1987-2006 period generally indicate greater streamflow than statistics for the entire periods of record. Two major factors contribute to this: First, the historic drought of the 1950s (Bomar, 1995) resulted in several years of much-below-normal streamflow. Second, the construction of Canyon Dam and Lake in the early 1960s affected streamflow on the Guadalupe River downstream from New Braunfels. As an example of the effect of the 1950s drought, mean annual streamflow at station 08167000 Guadalupe River at Comfort (upstream from Canyon Lake) was 323 cubic feet per second during water years 1987-2006. However, during 1940-2006, the mean annual streamflow was 229 cubic feet per second (about 29 percent less). Comal Springs stopped flowing during June-October 1956. During the same period, the Guadalupe River from Comfort to New Braunfels flowed intermittently. San Marcos Springs reached a historical minimum daily mean flow of 46 cubic feet per second on August 15, 1956. Streamflow at station 08176500 Guadalupe River at Victoria was sustained by San Marcos Springs and reached a historical minimum daily mean flow of 14 cubic feet per second on August 20, 1956.

\section{Reported Within-Reach Discharges and Withdrawals}

Reported (TCEQ permitted), within-reach discharge and withdrawal data were obtained from TCEQ. Discharge data for 1992-2006 were obtained in the form of monthly totals (Robert Organ, Texas Commission on Environmental Quality, written commun., 2007). Withdrawal data for 1991-2006 also were in the form of monthly totals (Ceasar Alvarado, Texas Commission on Environmental Quality, written 
commun., 2007). For both datasets, average monthly totals for available periods were used to estimate averages for the entire 1987-2006 period. For the short-term analysis periods, the reported monthly discharge and withdrawal totals were used, if available. If totals for a particular monthly period were not available, the average monthly inflow and outflow were used for the analysis.

\section{Analyses of Streamflow Conditions for Water Years 1987-2006}

For each stream reach listed in table 2, computations were done to obtain the following streamflow conditions, as summarized in table 4:

- Average streamflow at upstream and downstream gaging stations

- Average measured within-reach inflow from tributaries and major springs

- Average total within-reach gain or loss of streamflow, defined as the difference between average streamflow at the downstream station and average streamflow at the upstream station

- Average reported within-reach discharge inflow

- Average reported within-reach withdrawal

- Average adjusted within-reach gain/loss of streamflow, defined as the average total gain (or loss) plus average reported withdrawal minus average measured tributary and springs inflow minus average reported discharge inflow. This component also includes the sum of unmeasured or unreported streamflow components entering or exiting the reach. Such components include intervening runoff, evaporation, streamflow infiltration losses, unreported discharges and withdrawals, and streamflow-gaging measurement error.

- Cumulative average reported discharge inflow and withdrawal upstream from the reach outlet. These components represent, for each stream reach, the sum of all reported inflows and outflows upstream from, and including, those in the given reach. So, the cumulative inflows and outflows at lowermost reach 27 (Guadalupe River-Bloomington to San Antonio River) would represent the sum of reported discharge inflows and withdrawals for the entire study area.

- Cumulative average springflow from major springs upstream from, and including, those in the given reach.

- Average sum of inflows to each reach. The sum of inflows to the reach is an estimate of the total flow entering the river system within, and upstream from, the given reach. Inflows are quantified (measured or estimated) as they enter the river system. For example, measured releases from Canyon Lake enter the Guadalupe River in reach 9 and are considered inflows to all reaches of the river including and downstream from reach $9(18,21,22,26$, and 27). Other inflows include springflows, gaged tributary inflows, reported discharges, and intervening runoff and base flow.

Intervening runoff and base flow were estimated as the adjusted gain/loss in the reach.

- Ratio of springflow from major springs (Comal, San Marcos, and Hueco) to the sum of inflows to the reach, expressed as a percentage (for reaches of the Comal River and San Marcos River that include springflows from major springs, and the Guadalupe River reaches downstream from Canyon Dam). The ratio of springflow to the sum of inflows to the reach is an estimate of the contribution of flow from major springs to streamflow:

$\begin{gathered}\text { Contribution of springs } \\ \text { to streamflow }\end{gathered}=\frac{\text { Discharge }_{\text {springs }}}{\sum \text { Inflows }_{\text {source }}}$

where

$$
\begin{array}{r}
\text { Discharge }_{\text {springs }}= \\
\text { Inflows }_{\text {source }}=\begin{array}{l}
\text { total springflow of major springs, measured } \\
\text { at the spring source, and }
\end{array} \\
\quad \text { of inflow to the river system) entering the } \\
\text { reach of interest. }
\end{array}
$$

The contribution of springs to streamflow can be computed in other ways. Another way to estimate the contribution of springflow from major springs to streamflow is to compare springflow, after adjusting for losses (from withdrawals, evaporation, seepage) during travel downstream, to streamflow measured at the downstream point of interest:

$$
\begin{gathered}
\begin{array}{c}
\text { Contribution of } \\
\text { springs to } \\
\text { streamflow }
\end{array}
\end{gathered}=\frac{\text { Discharge }_{\text {springs }}-\text { Losses }_{\text {springflow }}}{Q_{\text {reach }}},
$$

where

$$
\begin{aligned}
\text { Discharge }_{\text {springs }}= & \begin{array}{c}
\text { total springflow of major springs, } \\
\text { measured at the spring source; }
\end{array} \\
\text { Losses }_{\text {springflow }}= & \text { losses to springflow (from evaporation, } \\
& \text { seepage, or withdrawals) as springflow } \\
& \text { travels downstream to the reach of } \\
& \text { interest; and } \\
\mathrm{Q}_{\text {reach }}= & \text { measured streamflow in the reach of } \\
& \text { interest. }
\end{aligned}
$$

Equation 1 involves values of streamflow components measured or estimated at the point where they enter the river system. Equation 2 involves values of streamflow components measured or estimated at the reach of interest. The advantage of equation 2 is that the denominator is obtained from measured streamflow. The difficulty with equation 2 is determining, or estimating, losses from springflow as it travels downstream. Also, springflows from the major springs originate from three locations and are subject to varying losses under different conditions. Given the difficulties associated with computing losses to springflow, estimates of the contribution of springflow to streamflow were computed using equation 1. 
Table 4. Summary of average streamflow conditions for 1987-2006 by stream reach, Guadalupe River Basin, south-central Texas. [In cubic feet per second except as indicated; --, not applicable;]

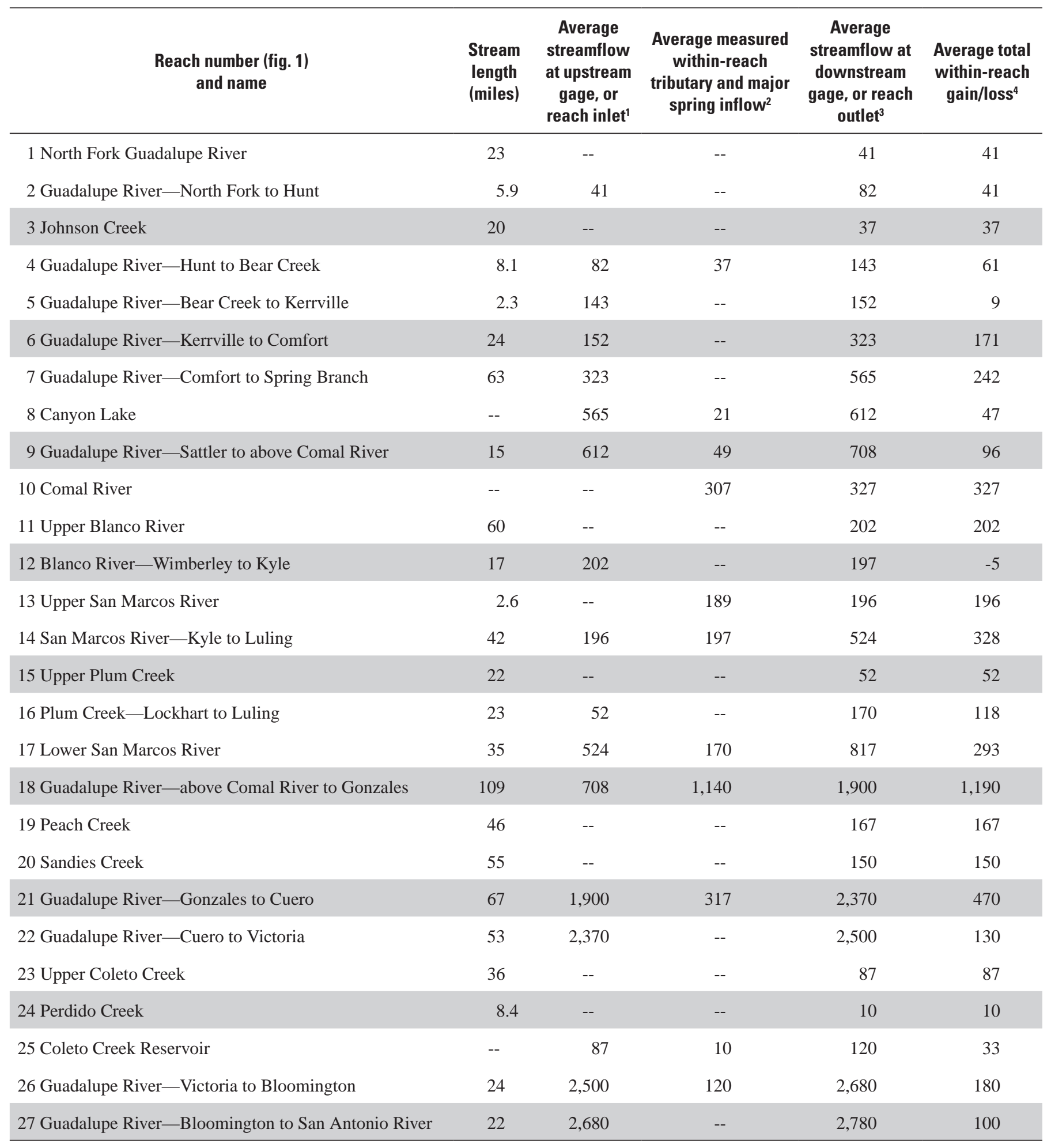

${ }^{1}$ Upstream streamflow for reach 27 estimated as (streamflow at downstream outlet of reach 26$)+($ estimated adjusted within-reach gain/loss) $+($ reported discharges) - (reported withdrawals).

${ }^{2}$ Average within-reach tributary inflows to reach 8, Canyon Lake, also include estimates of ungaged runoff, direct rainfall on lake surface, and evaporative losses; average within-reach tributary inflow to reach 8 computed as (estimated ungaged runoff) + (direct rainfall) - (evaporative losses).

${ }^{3}$ Downstream streamflows for reaches 17, 26, and 27 estimated as (streamflow at upstream gaging station) + (within-reach tributary inflow) $+($ estimated adjusted gain/loss) + (reported discharges) - (reported withdrawals). 


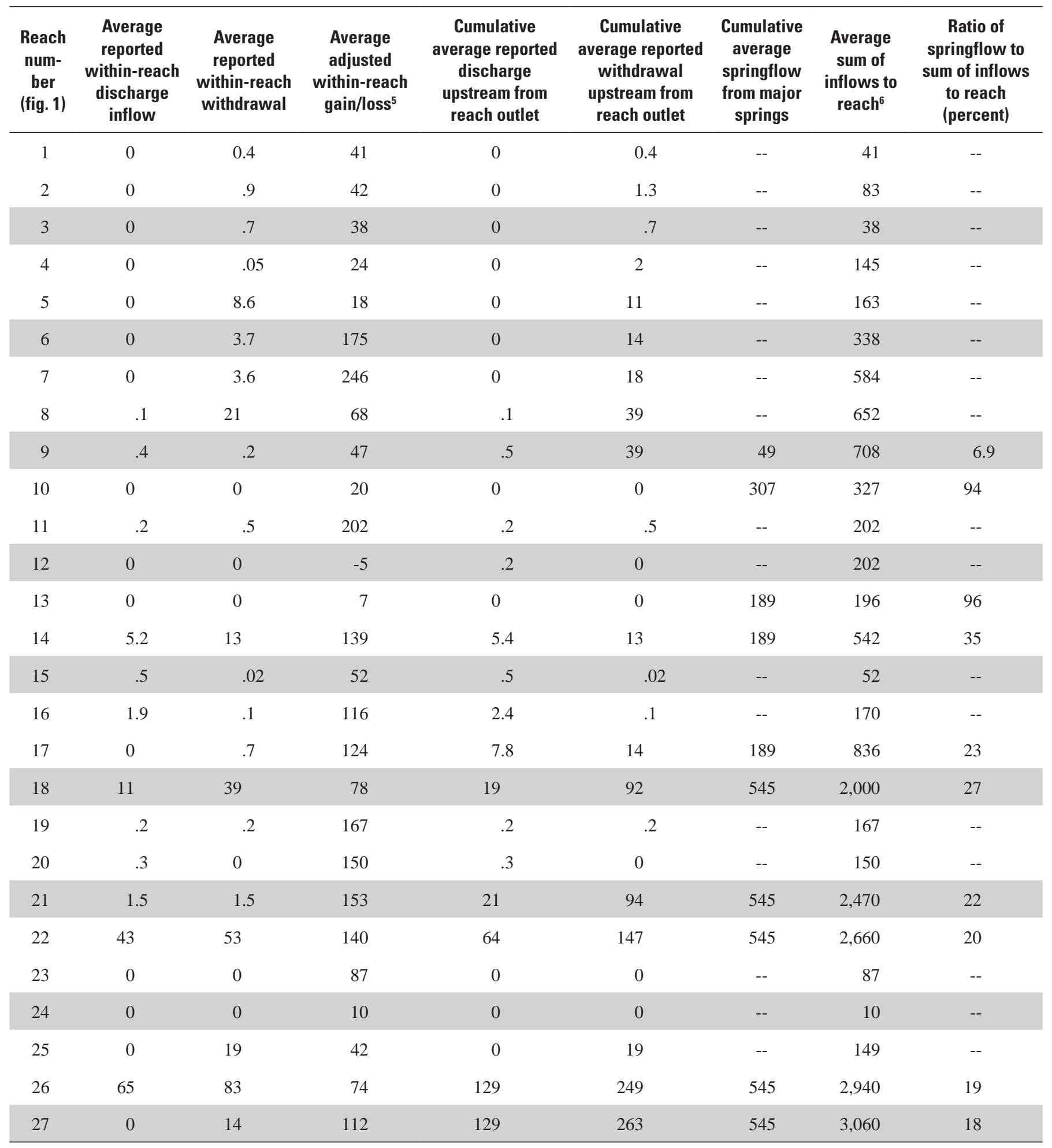

${ }^{4}$ Total within-reach gain/loss $=($ average downstream streamflow $)-($ average upstream streamflow $)$.

${ }^{5}$ Adjusted gain/loss $=$ (total gain/loss) + (reported within-reach withdrawals $)-($ tributary and major spring inflows $)-($ within-reach discharges $)$.

${ }^{6}$ Average sum of inflows to reach $=$ (sum of inflows from entering upstream and tributary reaches, except for reach 9 which only includes streamflow entering from upstream reach 8$)+($ springflow originating within reach, for reaches 9,10 , and 13 only $)+($ average adjusted within-reach gain/loss $)+($ reported withinreach discharges). 
For 1987-2006, total and adjusted within-reach gain/loss in 26 of 27 reaches is positive-the reaches gained streamflow (table 4). Most of the 26 gaining reaches incurred substantial gains, likely because of intervening runoff and base flow. Reach 12 (Blanco River-Wimberley to Kyle) lost streamflow, about 2.5 percent of inflow at the upstream reach boundary. Losses in this reach are attributed to infiltration to the Edwards aquifer recharge zone (outcrop) (Puente, 1978). Results of gain/loss studies by Slade and others (2002) also indicate losses to streamflow in reach 12 .

The ratio of springflow from the major springs to the sum of inflows for the first reach that includes inflow from all three major springs, reach 18 (Guadalupe River-above Comal River to Gonzales) is 27 percent. At the lowermost downstream reach, 27 (Guadalupe River-Bloomington to San Antonio River), the percentage of streamflow attributed to springflow is reduced to 18 percent because of the effects of tributary inflows (intervening reaches 19, 20, and 25) and reported discharges (intervening reaches 22 and 26).

Flow from Comal Springs into reach 10 (Comal River) accounted for about 94 percent of the total inflow to that reach during 1987-2006. Flow from San Marcos Springs into reach 13 (upper San Marcos River) accounted for 96 percent of the inflow to reach 13. San Marcos Springs flow was reduced to 35 percent of the inflow to reach 14 (San Marcos River-Kyle to Luling) because of intervening inflow from the Blanco River. The contribution of San Marcos Springs to the inflow to reach 17 (lower San Marcos River) was further reduced to about 23 percent because of the intervening inflow from Plum Creek in that reach. Hueco Springs flows into reach 9 (Guadalupe River-Sattler to above Comal River) and contributed about 6.9 percent of the inflow to that reach.

For reach 27, the most downstream reach, cumulative average reported discharges accounted for 129 cubic feet per second, compared with average sum of inflows of 3,060 cubic feet per second during 1987-2006; cumulative average reported withdrawals were 263 cubic feet per second. Most of the reported discharges and withdrawals occur in reach 22 (Guadalupe River-Cuero to Victoria) and reach 26 (Guadalupe River-Victoria to Bloomington). Additional major withdrawals from the Guadalupe River occur downstream from reach 27 , outside the study area.

Releases from Canyon Lake (reach 8) averaged 612 cubic feet per second during 1987-2006. Compared with cumulative average springflow from major springs (545 cubic feet per second) in reach 18 (Guadalupe River-above Comal River to Gonzales), Canyon Lake releases (streamflow at outlet of reach 8 ) accounted for a slightly higher percentage of streamflow at downstream reaches. At reach 27, the ratio of Canyon Lake releases to average sum of inflows was 20 percent, compared with the ratio of springflow to average sum of inflows of 18 percent.

\section{Analyses of Streamflow Conditions for Selected Short-Term Periods}

Analyses similar to those done for 1987-2006 were done for four short-term periods: January 1999, August 1999, August 2000, and August 2006. These periods were selected to represent a variety of relatively steady-state flow conditions, including low-flow periods. These analyses provide additional understanding of streamflow gains and losses and contributions of springflows to streamflows in the GRB during steadystate and low-flow periods.

Table 5 shows average springflows at the three major springs for the four monthly base-flow periods compared with long-term springflow statistics. January 1999 represents a

Table 5. Average springflows at major springs for selected short-term periods compared with long-term flow statistics, Guadalupe River Basin, south-central Texas.

[In cubic feet per second; --, not applicable]

\begin{tabular}{|c|c|c|c|c|}
\hline Analysis period & Comal Springs & San Marcos Springs & Hueco Springs & Total springs \\
\hline January 1999 & 415 & 312 & 79 & 806 \\
\hline August 1999 & 318 & 147 & 25 & 490 \\
\hline August 2000 & 177 & 124 & 7.7 & 309 \\
\hline Long-term statistical period & 1929-2006 & 1957-2006 & 1944-2006 & -- \\
\hline Mean & 290 & 175 & 42 & -- \\
\hline 20-percent exceedance & 356 & 222 & 78 & -- \\
\hline 50-percent exceedance (median) & 305 & 162 & 35 & -- \\
\hline
\end{tabular}


period when flows from all springs were greater than longterm median springflows. Streamflows upstream from Canyon Lake generally were near or greater than median streamflows. Streamflows downstream from Canyon Lake, including those of tributaries, generally were greater than median streamflows.

During August 1999 springflow at Comal Springs was slightly greater than the long-term median, and flows at San Marcos and Hueco Springs were less than their respective medians. In August 1999, most streamflows throughout the GRB were less than median 1987-2006 streamflows. During August 2000 springflows at all springs were low-at or near the long-term 90-percent exceedance values. Streamflows throughout the GRB also were relatively low. As an example, average streamflow at station 08176500 Guadalupe River at Victoria was 290 cubic feet per second compared with the 90-percent exceedance flow of 485 cubic feet per second. During August 2006, total springflow was about the same as in August 2000, although the distribution of springflow among the springs was different. Comal Springs flow was higher in August 2006 than in August 2000, whereas Hueco and San Marcos Springs flows were lower in August 2006 than in August 2000. During August 2006, streamflows throughout the GRB were similar to those of August 2000, generally near or below 90-percent exceedance values.

Similar to the 1987-2006 analyses, computations were done for each of the short-term periods to obtain the following streamflow conditions, as summarized in table 6:

- Average streamflow at upstream and downstream gaging stations

- Average measured within-reach inflow from tributaries and major springs

- Total within-reach gain or loss of streamflow, defined as the difference between average streamflow at the downstream station and average streamflow at the upstream station

- Reported within-reach discharge inflow

- Reported within-reach withdrawal

- Adjusted within-reach gain or loss of streamflow, defined as the total gain (or loss) plus reported withdrawal minus measured tributary and springs inflow minus reported discharge inflow

- Cumulative reported discharge inflow and withdrawal upstream from the reach outlet. These components represent, for each stream reach, the sum of all reported inflows and outflows upstream from, and including, those in the given reach

- Cumulative average springflow from major springs upstream from, and including, the given reach

- Sum of inflows to each reach.

- Ratio of springflow from major springs (Comal, San Marcos, and Hueco) to the sum of inflows to the reach, expressed as a percentage (for reaches of the Comal River and San Marcos River that include springflows from major springs, and the Guadalupe River reaches downstream from Canyon Dam).

During January 1999, streamflow increased for most reaches for which gain/loss computations could be made (table 6); streamflow decreased in reaches 12 and 25 (indicated either by negative values of average within-reach gain/ loss or by negative values of adjusted within-reach gain/loss). During August 1999, streamflow decreased in four reaches (5, 9, 12, and 15). During the short-term period with the lowest streamflows, August 2000, streamflow decreased in nine reaches $(4,5,6,7,9,12,14,15$, and 18). Streamflow in 11 reaches decreased during one or more of the four short-term periods. Only in reach 12 did streamflow decrease in all four periods. Gains and losses for reach 8, Canyon Lake, and reach 25, Coleto Creek Reservoir, are affected by reservoir operations and do not take into account storage conditions in the reservoir; gain/loss computations only reflect the difference between inflows and outflows measured at gaging stations. Although inflow exceeded outflow for the Canyon Lake reach during each short-term period, storage in the reservoir might actually have decreased.

During the four short-term periods, springflow from Hueco Springs accounted for 11-16 percent of the sum of inflows in reach 9 (Guadalupe River-Sattler to above Comal River). Flow from Comal Springs accounted for all inflows in reach 10 (Comal River). In reach 13 (upper San Marcos River), flow from San Marcos Springs accounted for all inflows during the short-term periods. Downstream in reach 14 (San Marcos River-Kyle to Luling), springflow was 60-87 percent of inflows. In the next downstream reach, reach 17 (lower San Marcos River), springflow was 52-85 percent of inflows during the four periods.

Reach 18 (Guadalupe River-above Comal River to Gonzales) is the most upstream reach that includes flows from all three major springs. During August 2000 and August 2006 (periods of relatively low flow), springflow accounted for 77 and 78 percent, respectively, of inflows in that reach. These percentages are considerably greater than the 27 percent that springflow accounted for during 1987-2006 (table 4). Farther downstream, the contribution of springflow during August 2000 and August 2006, as during 1987-2006, decreased because of tributary inflow and reported discharge inflows. At reach 26 (Guadalupe River-Victoria to Bloomington), springflow accounted for 57 and 56 percent of inflows, respectively, in August 2000 and August 2006 (table 6). At reach 27 (Guadalupe River-Bloomington to San Antonio River), springflow was 52 and 53 percent of inflows, respectively, during August 2000 and August 2006. The comparable percentage at reach 27 during 1987-2006 was 18 percent (table 4).

During the short-term periods, reported discharge inflows and withdrawals (table 6) were similar to average reported discharge inflows and withdrawals for 1987-2006 (table 4). However, during low-flow periods, discharge inflows and withdrawals account for substantially larger percentages of the sum 
Table 6. Summary of streamflow conditions for selected short-term periods by stream reach, Guadalupe River Basin, south-central [In cubic feet per second except as indicated; --, not applicable or not available]

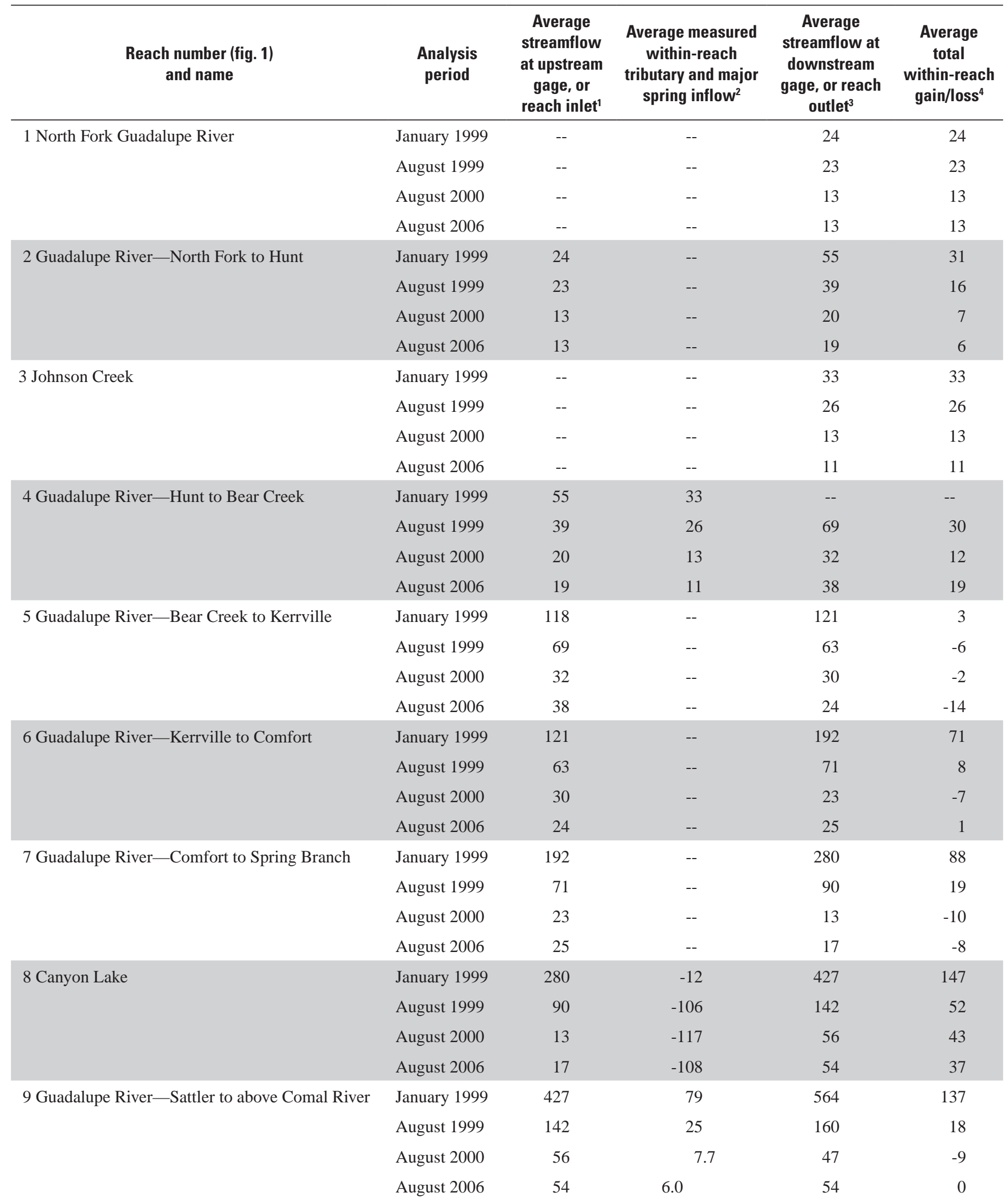

See footnotes at end of table. 
Texas.

\begin{tabular}{|c|c|c|c|c|c|c|c|c|}
\hline $\begin{array}{l}\text { Reach } \\
\text { num- } \\
\text { ber } \\
\text { (fig. 1) }\end{array}$ & $\begin{array}{l}\text { Reported } \\
\text { within-reach } \\
\text { discharge } \\
\text { inflow }\end{array}$ & $\begin{array}{c}\text { Reported } \\
\text { within-reach } \\
\text { withdrawal }\end{array}$ & $\begin{array}{c}\text { Adjusted } \\
\text { within-reach } \\
\text { gain/loss }\end{array}$ & $\begin{array}{l}\text { Cumulative } \\
\text { reported } \\
\text { discharge } \\
\text { upstream from } \\
\text { reach outlet }\end{array}$ & $\begin{array}{l}\text { Cumulative } \\
\text { reported } \\
\text { withdrawal } \\
\text { upstream from } \\
\text { reach outlet } \\
\end{array}$ & $\begin{array}{l}\text { Cumulative } \\
\text { average } \\
\text { springflow } \\
\text { from major } \\
\text { springs } \\
\end{array}$ & $\begin{array}{c}\text { Sum of } \\
\text { inflows } \\
\text { to reach }\end{array}$ & $\begin{array}{c}\text { Ratio of } \\
\text { springflow to } \\
\text { sum of inflows } \\
\text { to reach } \\
\text { (percent) } \\
\end{array}$ \\
\hline \multirow[t]{4}{*}{1} & 0 & 0.4 & 24 & 0 & 0.4 & -- & 24 & -- \\
\hline & 0 & .5 & 24 & 0 & .5 & -- & 24 & -- \\
\hline & 0 & .5 & 14 & 0 & .5 & -- & 14 & -- \\
\hline & 0 & .4 & 13 & 0 & .4 & -- & 13 & -- \\
\hline \multirow[t]{4}{*}{2} & 0 & .9 & 32 & 0 & 1.3 & -- & 56 & -- \\
\hline & 0 & 1 & 17 & 0 & 1.5 & -- & 41 & -- \\
\hline & 0 & .9 & 8 & 0 & 1.4 & -- & 22 & -- \\
\hline & 0 & .9 & 7 & 0 & 1.3 & -- & 20 & -- \\
\hline \multirow[t]{4}{*}{3} & 0 & .6 & 34 & 0 & .6 & -- & 34 & -- \\
\hline & 0 & 1 & 27 & 0 & 1 & -- & 27 & -- \\
\hline & 0 & .7 & 14 & 0 & .7 & -- & 14 & -- \\
\hline & 0 & .7 & 12 & 0 & .7 & -- & 12 & -- \\
\hline \multirow[t]{4}{*}{4} & 0 & .04 & -- & 0 & 1.9 & -- & 92 & -- \\
\hline & 0 & .05 & 4 & 0 & 2.6 & -- & 72 & -- \\
\hline & 0 & .05 & -1 & 0 & 2.2 & -- & 35 & -- \\
\hline & 0 & .05 & 8 & 0 & 2.1 & -- & 40 & -- \\
\hline \multirow[t]{4}{*}{5} & 0 & 5.4 & 8 & 0 & 7 & -- & 100 & -- \\
\hline & 0 & 6.3 & 0 & 0 & 9 & -- & 72 & -- \\
\hline & 0 & 8.6 & 7 & 0 & 11 & -- & 42 & -- \\
\hline & 0 & 4.1 & -10 & 0 & 6 & -- & 40 & -- \\
\hline \multirow[t]{4}{*}{6} & 0 & 3.4 & 74 & 0 & 11 & -- & 174 & -- \\
\hline & 0 & 5.2 & 13 & 0 & 14 & -- & 85 & -- \\
\hline & 0 & 4.4 & -3 & 0 & 15 & -- & 42 & -- \\
\hline & 0 & 3.9 & 5 & 0 & 10 & -- & 45 & -- \\
\hline \multirow[t]{4}{*}{7} & 0 & 3.4 & 91 & 0 & 14 & -- & 266 & -- \\
\hline & 0 & 3.6 & 23 & 0 & 18 & -- & 108 & -- \\
\hline & 0 & 3.4 & -7 & 0 & 19 & -- & 42 & -- \\
\hline & 0 & 3.2 & -5 & 0 & 13 & -- & 45 & -- \\
\hline \multirow[t]{4}{*}{8} & .05 & 5.8 & 165 & .05 & 20 & -- & 431 & -- \\
\hline & .09 & 24 & 182 & .09 & 42 & -- & 290 & -- \\
\hline & .09 & 21 & 181 & .09 & 40 & -- & 222 & -- \\
\hline & .09 & 70 & 215 & .09 & 83 & -- & 260 & -- \\
\hline \multirow[t]{4}{*}{9} & .3 & .3 & 58 & .4 & 20 & 79 & 564 & 14 \\
\hline & .3 & .3 & -7 & .4 & 42 & 25 & 160 & 16 \\
\hline & .3 & .3 & -17 & .4 & 39 & 7.7 & 47 & 16 \\
\hline & .3 & .3 & -6 & .4 & 83 & 6.0 & 54 & 11 \\
\hline
\end{tabular}

See footnotes at end of table. 
Table 6. Summary of streamflow conditions for selected short-term periods by stream reach, Guadalupe River Basin, south-central

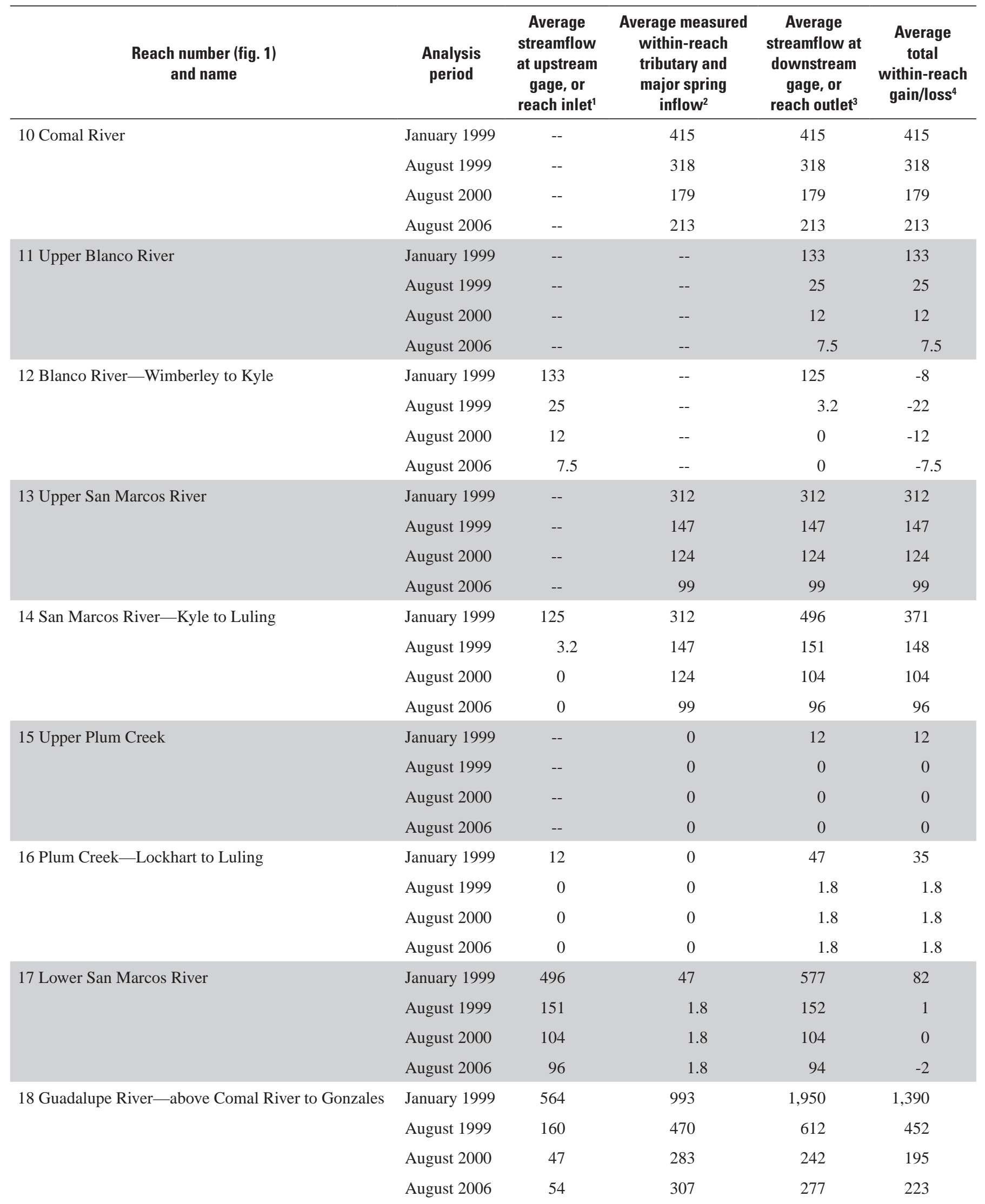

See footnotes at end of table. 
Texas-Continued.

\begin{tabular}{|c|c|c|c|c|c|c|c|c|}
\hline $\begin{array}{c}\text { Reach } \\
\text { num- } \\
\text { ber } \\
\text { (fig. 1) }\end{array}$ & $\begin{array}{l}\text { Reported } \\
\text { within-reach } \\
\text { discharge } \\
\text { inflow }\end{array}$ & $\begin{array}{c}\text { Reported } \\
\text { within-reach } \\
\text { withdrawal }\end{array}$ & $\begin{array}{c}\text { Adjusted } \\
\text { within-reach } \\
\text { gain/loss }\end{array}$ & $\begin{array}{l}\text { Cumulative } \\
\text { reported } \\
\text { discharge } \\
\text { upstream from } \\
\text { reach outlet }\end{array}$ & $\begin{array}{l}\text { Cumulative } \\
\text { reported } \\
\text { withdrawal } \\
\text { upstream from } \\
\text { reach outlet }\end{array}$ & $\begin{array}{l}\text { Cumulative } \\
\text { average } \\
\text { springflow } \\
\text { from major } \\
\text { springs }\end{array}$ & $\begin{array}{l}\text { Sum of } \\
\text { inflows to } \\
\text { reach }^{6}\end{array}$ & $\begin{array}{c}\text { Ratio of } \\
\text { springflow to } \\
\text { sum of inflows } \\
\text { to reach } \\
\text { (percent) }\end{array}$ \\
\hline \multirow[t]{4}{*}{10} & 0 & 0 & 0 & 0 & 0 & 415 & 415 & 100 \\
\hline & 0 & 0 & 0 & 0 & 0 & 318 & 318 & 100 \\
\hline & 0 & 0 & 0 & 0 & 0 & 177 & 179 & 100 \\
\hline & 0 & 0 & 0 & 0 & 0 & 213 & 213 & 100 \\
\hline \multirow[t]{4}{*}{11} & .2 & .4 & 133 & .2 & .4 & -- & 133 & -- \\
\hline & .2 & .5 & 25 & .2 & .5 & -- & 26 & -- \\
\hline & .2 & .5 & 12 & .2 & .5 & -- & 113 & -- \\
\hline & .2 & .5 & 8 & .2 & .5 & -- & 8.0 & -- \\
\hline \multirow[t]{4}{*}{12} & 0 & 0 & -8 & .2 & .4 & -- & 133 & -- \\
\hline & 0 & 0 & -22 & .2 & .5 & -- & 26 & -- \\
\hline & 0 & 0 & -12 & .2 & .5 & -- & 113 & -- \\
\hline & 0 & 0 & -8 & .2 & .5 & -- & 8.0 & -- \\
\hline \multirow[t]{4}{*}{13} & 0 & 0 & 0 & 0 & 0 & 312 & 312 & 100 \\
\hline & 0 & 0 & 0 & 0 & 0 & 147 & 147 & 100 \\
\hline & 0 & 0 & 0 & 0 & 0 & 124 & 124 & 100 \\
\hline & 0 & 0 & 0 & 0 & 0 & 99 & 99 & 100 \\
\hline \multirow[t]{4}{*}{14} & 6.6 & 12 & 64 & 6.8 & 12 & 312 & 516 & 60 \\
\hline & 5.6 & 14 & 9 & 5.8 & 14 & 147 & 187 & 78 \\
\hline & 5.6 & 13 & -13 & 5.8 & 14 & 124 & 142 & 87 \\
\hline & 5.9 & 13 & 4 & 6.1 & 14 & 99 & 99 & 85 \\
\hline \multirow[t]{4}{*}{15} & .4 & .02 & 12 & .4 & .02 & -- & 12 & -- \\
\hline & 1.0 & 0 & -1 & 1.0 & 0 & -- & 1.0 & -- \\
\hline & 1.3 & 0 & -1 & 1.3 & 0 & -- & 1.3 & -- \\
\hline & 1.4 & 0 & -1 & 1.4 & 0 & -- & 1.4 & -- \\
\hline \multirow[t]{4}{*}{16} & 2.3 & .1 & 33 & 2.7 & .1 & -- & 48 & -- \\
\hline & 1.2 & .1 & 1 & 2.2 & .1 & -- & 3.2 & -- \\
\hline & 1.9 & .1 & 0 & 3.2 & .1 & -- & 3.2 & -- \\
\hline & 1.9 & .1 & 0 & 3.3 & .1 & -- & 3.3 & -- \\
\hline \multirow[t]{4}{*}{17} & .8 & 1.6 & 35 & 10 & 14 & 312 & 600 & 52 \\
\hline & .6 & 2.4 & 1 & 9 & 17 & 147 & 192 & 77 \\
\hline & .7 & 2.2 & 0 & 10 & 16 & 124 & 146 & 85 \\
\hline & .7 & 4.8 & 0 & 10 & 19 & 99 & 121 & 82 \\
\hline \multirow[t]{4}{*}{18} & 11 & 13 & 399 & 22 & 47 & 806 & 1,990 & 41 \\
\hline & 11 & 44 & 15 & 20 & 103 & 490 & 703 & 70 \\
\hline & 11 & 43 & -56 & 21 & 98 & 309 & 400 & 77 \\
\hline & 11 & 39 & -56 & 21 & 141 & 318 & 406 & 78 \\
\hline
\end{tabular}

See footnotes at end of table. 
Table 6. Summary of streamflow conditions for selected short-term periods by stream reach, Guadalupe River Basin, south-central

\begin{tabular}{|c|c|c|c|c|c|}
\hline $\begin{array}{l}\text { Reach number (fig. 1) } \\
\text { and name }\end{array}$ & $\begin{array}{l}\text { Analysis } \\
\text { period }\end{array}$ & $\begin{array}{c}\text { Average } \\
\text { streamflow } \\
\text { at upstream } \\
\text { gage, or } \\
\text { reach inlet }^{1}\end{array}$ & $\begin{array}{l}\text { Average measured } \\
\text { within-reach } \\
\text { tributary and } \\
\text { major spring } \\
\text { inflow }{ }^{2}\end{array}$ & $\begin{array}{c}\text { Average } \\
\text { streamflow } \\
\text { at down- } \\
\text { stream gage, } \\
\text { or } \\
\text { reach outlet }^{3}\end{array}$ & $\begin{array}{c}\text { Average } \\
\text { total } \\
\text { within-reach } \\
\text { gain/loss }^{4}\end{array}$ \\
\hline \multirow[t]{2}{*}{19 Peach Creek } & January 1999 & -- & -- & -- & -- \\
\hline & August 2006 & -- & -- & 1.1 & 1.1 \\
\hline \multirow[t]{3}{*}{20 Sandies Creek } & January 1999 & -- & -- & 43 & 43 \\
\hline & August 1999 & -- & -- & 4.2 & 4.2 \\
\hline & August 2000 & -- & -- & 1.5 & 1.5 \\
\hline \multirow{2}{*}{21 Guadalupe River-Gonzales to Cuero } & August 2000 & 242 & 1.5 & 282 & 40 \\
\hline & August 2006 & 277 & .2 & 288 & 11 \\
\hline \multirow[t]{4}{*}{22 Guadalupe River - Cuero to Victoria } & January 1999 & 2,180 & -- & 2,210 & 30 \\
\hline & August 1999 & 672 & -- & 714 & 42 \\
\hline & August 2000 & 282 & -- & 290 & 8 \\
\hline & August 2006 & 288 & -- & 296 & 8 \\
\hline \multirow[t]{3}{*}{23 Upper Coleto Creek } & January 1999 & -- & 0 & 31 & 31 \\
\hline & August 1999 & -- & 0 & 3.4 & 3.4 \\
\hline & August 2000 & -- & 0 & 0 & 0 \\
\hline \multirow[t]{4}{*}{25 Coleto Creek Reservoir } & January 1999 & 31 & 2.9 & 24 & -7.0 \\
\hline & August 1999 & 3.4 & .3 & 4.6 & 1.2 \\
\hline & August 2000 & 0 & 0 & 3.9 & 3.9 \\
\hline & August 2006 & 1.1 & 0 & 4.5 & 3.4 \\
\hline \multirow[t]{4}{*}{26 Guadalupe River-Victoria to Bloomington } & January 1999 & 2,210 & 24 & 2,230 & 20 \\
\hline & August 1999 & 714 & 4.6 & 723 & 9 \\
\hline & August 2000 & 290 & 3.9 & 310 & 20 \\
\hline & August 2006 & 296 & 4.5 & 308 & 12 \\
\hline \multirow[t]{4}{*}{27 Guadalupe River-Bloomington to San Antonio River } & January 1999 & 2,230 & -- & 2,240 & 10 \\
\hline & August 1999 & 723 & -- & 743 & 20 \\
\hline & August 2000 & 310 & -- & 347 & 37 \\
\hline & August 2006 & 308 & -- & 333 & 25 \\
\hline
\end{tabular}

\footnotetext{
${ }^{1}$ Upstream streamflow for reach 27 estimated as (streamflow at downstream outlet of reach 26) + (estimated adjusted within-reach gain/loss) $+($ reported discharges) - (reported withdrawals).

${ }^{2}$ Average within-reach tributary inflows to reach 8, Canyon Lake, also include estimates of ungaged runoff, direct rainfall on lake surface, and evaporative losses; average within-reach tributary inflow to reach 8 computed as (estimated ungaged runoff) + (direct rainfall) - (evaporative losses).

${ }^{3}$ Downstream streamflows for reaches 17, 26, and 27 estimated as (streamflow at upstream gaging station) $+($ within-reach tributary inflow) $+($ estimated adjusted gain/loss) + (reported discharges) - (reported withdrawals).
} 
Texas-Continued.

\begin{tabular}{|c|c|c|c|c|c|c|c|c|}
\hline $\begin{array}{l}\text { Reach } \\
\text { number } \\
\text { (fig. 1) }\end{array}$ & $\begin{array}{l}\text { Reported } \\
\text { within-reach } \\
\text { discharge } \\
\text { inflow }\end{array}$ & $\begin{array}{c}\text { Reported } \\
\text { within-reach } \\
\text { withdrawal }\end{array}$ & $\begin{array}{c}\text { Adjusted } \\
\text { within-reach } \\
\text { gain/loss }\end{array}$ & $\begin{array}{l}\text { Cumulative re- } \\
\text { ported discharge } \\
\text { upstream from } \\
\text { reach outlet }\end{array}$ & $\begin{array}{l}\text { Cumulative } \\
\text { reported } \\
\text { withdrawals } \\
\text { upstream from } \\
\text { reach outlet }\end{array}$ & $\begin{array}{l}\text { Cumulative } \\
\text { average } \\
\text { springflow } \\
\text { from major } \\
\text { springs }\end{array}$ & $\begin{array}{c}\text { Sum of } \\
\text { inflows } \\
\text { to reach }\end{array}$ & $\begin{array}{l}\text { Ratio of } \\
\text { springflow } \\
\text { to sum of in- } \\
\text { flows to reach } \\
\text { (percent) }\end{array}$ \\
\hline \multirow[t]{4}{*}{19} & 0.1 & 0.2 & -- & 0.1 & 0.2 & -- & -- & -- \\
\hline & .1 & .2 & -- & .1 & .2 & -- & -- & -- \\
\hline & .1 & .2 & -- & .1 & .2 & -- & -- & -- \\
\hline & .2 & .2 & 1 & .2 & .2 & -- & 1.2 & -- \\
\hline \multirow[t]{4}{*}{20} & .3 & 0 & 43 & .3 & 0 & -- & 43 & -- \\
\hline & .3 & 0 & 4 & .3 & 0 & -- & 4.3 & -- \\
\hline & .3 & 0 & 1 & .3 & 0 & -- & 1.3 & -- \\
\hline & .3 & 0 & 0 & .3 & 0 & -- & 0.3 & -- \\
\hline \multirow[t]{4}{*}{21} & 2.3 & .4 & 185 & 24 & 47 & 806 & 2,220 & 36 \\
\hline & 2.3 & 4.1 & 58 & 23 & 107 & 490 & 768 & 64 \\
\hline & 2.3 & 2.6 & 39 & 24 & 101 & 309 & 442 & 70 \\
\hline & 2.3 & 4.5 & 13 & 24 & 145 & 318 & 422 & 75 \\
\hline \multirow[t]{4}{*}{22} & 43 & 44 & 31 & 67 & 91 & 806 & 2,290 & 35 \\
\hline & 55 & 76 & 42 & 78 & 183 & 490 & 879 & 56 \\
\hline & 38 & 45 & 15 & 62 & 146 & 309 & 422 & 73 \\
\hline & 43 & 83 & 48 & 67 & 228 & 318 & 451 & 70 \\
\hline \multirow[t]{4}{*}{23} & 0 & 0 & 31 & 0 & 0 & -- & 31 & -- \\
\hline & 0 & 0 & 3 & 0 & 0 & -- & 3.0 & -- \\
\hline & 0 & 0 & 0 & 0 & 0 & -- & 0 & -- \\
\hline & 0 & 0 & 1 & 0 & 0 & -- & 1.0 & -- \\
\hline \multirow[t]{4}{*}{24} & -- & -- & -- & -- & -- & -- & -- & -- \\
\hline & -- & -- & -- & -- & -- & -- & -- & -- \\
\hline & -- & -- & -- & -- & -- & -- & -- & -- \\
\hline & -- & -- & -- & -- & -- & -- & -- & -- \\
\hline \multirow[t]{4}{*}{25} & 0 & 19 & 9 & 0 & 19 & -- & 40 & -- \\
\hline & 0 & 19 & 20 & 0 & 19 & -- & 23 & -- \\
\hline & 0 & 19 & 23 & 0 & 19 & -- & 23 & -- \\
\hline & 0 & 19 & 22 & 0 & 19 & -- & 23 & -- \\
\hline \multirow[t]{4}{*}{26} & 65 & 83 & 14 & 132 & 193 & 806 & 2,410 & 33 \\
\hline & 65 & 83 & 22 & 143 & 285 & 490 & 989 & 50 \\
\hline & 65 & 83 & 34 & 127 & 248 & 309 & 544 & 57 \\
\hline & 65 & 83 & 26 & 132 & 330 & 318 & 565 & 56 \\
\hline \multirow[t]{4}{*}{27} & 0 & 14 & 24 & 132 & 207 & 806 & 2,430 & 33 \\
\hline & 0 & 14 & 34 & 143 & 299 & 490 & 1,020 & 48 \\
\hline & 0 & 14 & 51 & 127 & 262 & 309 & 595 & 52 \\
\hline & 0 & 14 & 39 & 132 & 344 & 318 & 604 & 53 \\
\hline
\end{tabular}

${ }^{4}$ Total within-reach gain/loss = (average downstream streamflow) - (average upstream streamflow).

${ }^{5}$ Adjusted gain/loss $=($ total gain/loss $)+($ reported within-reach withdrawals $)-($ tributary and major spring inflows $)-($ within-reach discharges $)$.

${ }^{6}$ Sum of inflows to reach $=($ sum of inflows from entering upstream and tributary reaches, except for reach 9 which only includes streamflow entering from upstream reach 8$)+($ springflow originating within reach, for reaches 9,10 , and 13 only $)+($ adjusted within-reach gain/loss $)+($ reported within-reach discharges). 
Table 7. Comparison of contributions of Canyon Lake releases and flow from major springs to streamflow in selected stream reaches for selected short-term periods, Guadalupe River Basin, south-central Texas.

\begin{tabular}{|c|c|c|c|c|c|c|}
\hline $\begin{array}{l}\text { Reach number } \\
\text { and name }\end{array}$ & $\begin{array}{l}\text { Analysis } \\
\text { period }\end{array}$ & $\begin{array}{c}\text { Average } \\
\text { streamflow from } \\
\text { Canyon Lake } \\
\text { (cubic feet } \\
\text { per second) }\end{array}$ & $\begin{array}{l}\text { Cumulative } \\
\text { springflow from } \\
\text { major springs } \\
\text { (cubic feet } \\
\text { per second) }\end{array}$ & $\begin{array}{c}\text { Sum of inflows } \\
\text { to reach } \\
\text { (cubic feet } \\
\text { per second) }\end{array}$ & $\begin{array}{l}\text { Ratio of stream- } \\
\text { flow from Canyon } \\
\text { Lake to sum of } \\
\text { inflows to reach } \\
\text { (percent) }\end{array}$ & $\begin{array}{c}\text { Ratio of } \\
\text { springflow to } \\
\text { sum of inflows } \\
\text { to reach } \\
\text { (percent) }\end{array}$ \\
\hline \multirow{4}{*}{$\begin{array}{l}18 \text { Guadalupe River- } \\
\text { above Comal River to } \\
\text { Gonzales }\end{array}$} & January 1999 & 427 & 806 & 1,990 & 21 & 41 \\
\hline & August 1999 & 142 & 490 & 703 & 20 & 70 \\
\hline & August 2000 & 56 & 309 & 400 & 14 & 77 \\
\hline & August 2006 & 54 & 318 & 406 & 13 & 78 \\
\hline \multirow{4}{*}{$\begin{array}{l}22 \text { Guadalupe River- } \\
\text { Cuero to Victoria }\end{array}$} & January 1999 & 427 & 806 & 2,290 & 19 & 35 \\
\hline & August 1999 & 142 & 490 & 879 & 16 & 56 \\
\hline & August 2000 & 56 & 309 & 422 & 13 & 73 \\
\hline & August 2006 & 54 & 318 & 451 & 12 & 70 \\
\hline \multirow{4}{*}{$\begin{array}{l}26 \text { Guadalupe River- } \\
\text { Victoria to Bloom- } \\
\text { ington }\end{array}$} & January 1999 & 427 & 806 & 2,410 & 18 & 33 \\
\hline & August 1999 & 142 & 490 & 989 & 14 & 50 \\
\hline & August 2000 & 56 & 309 & 544 & 10 & 57 \\
\hline & August 2006 & 54 & 318 & 565 & 9.6 & 56 \\
\hline \multirow{4}{*}{$\begin{array}{l}27 \text { Guadalupe River- } \\
\text { Bloomington to San } \\
\text { Antonio River }\end{array}$} & January 1999 & 427 & 806 & 2,430 & 18 & 33 \\
\hline & August 1999 & 142 & 490 & 1,020 & 14 & 48 \\
\hline & August 2000 & 56 & 309 & 595 & 9.4 & 52 \\
\hline & August 2006 & 54 & 318 & 604 & 8.9 & 53 \\
\hline
\end{tabular}

of inflows than those during 1987-2006. For example, during August 2006 (a low-flow period) combined reaches 22 and 26 reported discharge inflows accounted for 24 percent of the sum of inflows to reach 22. During the same period, withdrawals from reaches 22 and 26 accounted for about 37 percent of the sum of inflows to reach 22. During 1987-2006 (table 4), combined reach 22 and 26 reported discharge inflows accounted for 4.0 percent of sum of inflows, and withdrawals accounted for 5.0 percent of sum of inflows to reach 22 .

Similar to the computations indicating the contributions of springflow to the sum of inflows for selected short-term periods (table 6), contributions of releases from Canyon Lake (reach 8) to the sum of inflows were computed for selected reaches and are shown in table 7. Also shown for comparison are the ratios of springflow to the sum of inflows.

In contrast to Canyon Lake releases during 1987-2006 (table 4), Canyon Lake releases during the short-term periods accounted for smaller percentages of the sum of inflows at downstream reaches than springflows (table 6). During the relatively low-flow periods August 2000 and August 2006 for reach 27, the ratios of Canyon Lake releases to the sum of inflows were less than 10 percent. During those same periods, flow from major springs accounted for more than 50 percent of the sum of inflows for reach 27. During 1987-2006 for reach 27 (table 4), the ratio of Canyon Lake releases to the sum of inflows was 20 percent, and the ratio of springflow to the sum of inflows was 18 percent.

\section{Summary}

The U.S. Geological Survey, in cooperation with the Edwards Aquifer Authority, assessed available streamflow data in the Guadalupe River Basin (GRB) to determine streamflow gains and losses and the relative contribution of flow from major springs-Comal Springs, San Marcos Springs, and Hueco Springs - to streamflow in reaches of the Guadalupe River and its tributaries. The assessment is based primarily on long-term (20 years) and short-term (four 1-month base-flow periods) streamflow conditions.

The GRB was divided into a network of 27 stream reaches (13 Guadalupe River and 14 tributary), defined mainly by the locations of USGS streamflow-gaging stations. For each reach, streamflow data from the upstream and downstream gaging stations and intervening discharges (inflows) and withdrawals (outflows) were compiled. Water-budget analyses were done for water years 1987-2006 and for four short-term, base-flow periods, January 1999, August 1999, August 2000, and August 2006. For each analysis period, the ratio of flow from the major springs (measured at the 
spring source) to the sum of inflows (measured at the source of inflow to the river system) is computed for reaches of the Comal River and San Marcos River that include springflows from major springs, and for the Guadalupe River reaches downstream from Canyon Dam. The ratio of springflow to the sum of inflows to the reach is an estimate of the contribution of flow from major springs to streamflow.

For 1987-2006, 26 of the 27 reaches gained streamflow. Most of the 26 gaining reaches incurred substantial gains, likely because of intervening runoff and base flow. The ratio of springflow from the major springs to the sum of inflows for the most upstream reach that includes inflow from all three major springs, reach 18 (Guadalupe River-above Comal River to Gonzales) is 27 percent. At the lowermost downstream reach, 27 (Guadalupe River-Bloomington to San Antonio River), the percentage of the sum of inflows attributed to springflow is reduced to 18 percent because of the effects of tributary inflows (intervening reaches 19, 20, and 25) and reported (Texas Commission on Environmental Quality permitted), discharges (intervening reaches 22 and 26).

Compared with cumulative average springflow from major springs in reach 18, Canyon Lake releases (streamflow at outlet of reach 8) accounted for a slightly higher percentage of the sum of inflows at downstream reaches. At reach 27, the ratio of Canyon Lake releases to the sum of inflows was 20 percent, compared with the ratio of springflow to the sum of inflows of 18 percent.

The four short-term periods were selected to represent a variety of relatively steady-state flow conditions, including low-flow periods. During August 2000 and August 2006 (periods of relatively low flow), springflow in reach 18 (Guadalupe River-above Comal River to Gonzales), the most upstream reach that includes inflow from all three major springs, accounted for 77 and 78 percent, respectively, of the sum of inflows in that reach. These percentages are considerably greater than the 27 percent that springflow accounted for during 1987-2006. Farther downstream, the contribution of springflow to the sum of inflows during August 2000 and August 2006, as during 1987-2006, decreased because of tributary inflow and reported discharge inflows. At the most downstream reach, 27 (Guadalupe RiverBloomington to San Antonio River), springflow was 52 and 53 percent of the sum of inflows, respectively, during August 2000 and August 2006 (compared with 18 percent during 1987-2006).

In contrast to Canyon Lake releases during 1987-2006, Canyon Lake releases during the short-term periods accounted for smaller percentages of the sum of inflows at downstream reaches than springflows. During the relatively low-flow periods August 2000 and August 2006 for reach 27, the ratios of Canyon Lake releases to the sum of inflows were less than 10 percent (compared with 20 percent during 1987-2006). During those same periods, flow from major springs accounted for more than 50 percent of the sum of inflows for reach 27 (compared with 18 percent during 1987-2006).

\section{References}

Bomar, G.W., 1995, Texas weather (2d ed.): Austin, University of Texas Press, 275 p.

Brune, G., 1975, Major and historical springs of Texas: Texas Water Development Board Report 189, 91 p.

Guadalupe-Blanco River Authority, 2007a, Canyon Lake fact sheet: accessed October 10, 2007, at http://www.gbra.org/ $\mathrm{Public/C}$ anyonReservoir.aspx

Guadalupe-Blanco River Authority, 2007b, Coleto Creek Park and reservoir fact sheet: accessed October 10, 2007, at http://www.gbra.org/Recreation/C oletoC reek/D efault.aspx

Heitmuller, F.T., and Reece, B.D., 2003, Database of historically documented springs and spring flow measurements in Texas: U.S. Geological Survey Open-File Report 03-315, $1 \mathrm{CD}$.

Helsel, D.R., and Hirsch, R.M., 1992, Statistical methods in water resources-Studies in environmental science 49: Amsterdam, Elsevier, 522 p.

Larkin, T.J., and Bomar, G.W., 1983, Climatic atlas of Texas: Texas Department of Water Resources, Limited Printing Report LP-192, $151 \mathrm{p}$.

Puente, Celso, 1978, Method of estimating natural recharge to the Edwards aquifer in the San Antonio area, Texas: U.S. Geological Survey Water-Resources Investigations Report 78-10, $34 \mathrm{p}$.

Slade, R.M., Jr., Bentley, J.T,, and Michaud, Dana, 2002, Results of streamflow gain-loss studies in Texas, with emphasis on gains from and losses to major and minor aquifers: U.S. Geological Survey Open-File Report 02-068, 136 p., 2 plates.

U.S. Army Corps of Engineers, 2007, Fort Worth-Reservoir Control Section: accessed October 10, 2007, at http://www. swf-wc.usace.army.mil/cgi-bin/rcshtml.pl

U.S. Census Bureau, 2007, Texas state and county quick facts: accessed October 15, 2007, at http://quickfacts.census.gov/ $\mathrm{gfd} / \mathrm{states} / 48000 . \mathrm{html}$

U.S. Department of Commerce, National Oceanic and Atmospheric Administration, 2002, Climatography of the United States 81, Monthly station normals of temperature, precipitation, and heating and cooling degree days 1971-2000, Texas: Asheville, N.C., National Climatic Data Center, v. 41,88 p.

U.S. Environmental Protection Agency, 2008, Watershed academy-Hydrology: accessed September 11, 2008, at http://www.epa.gov/owow/watershed/wacademy/wam/ hydrology.html 
22 Streamflow Conditions in the Guadalupe River Basin, South-Central Texas, Water Years 1987-2006

U.S. Geological Survey, 2007, Water-resources data for the United States, water year 2006: U.S. Geological Survey Water-Data Report WDR-US-2006, accessed January 4, 2007, at http://wdr.water.usgs.gov/wy2006/search.jsp
U.S. Geological Survey, 2008, National Water Information System (NWISWeb) [for Texas] data available on the World Wide Web at http://waterdata.usgs.gov/tx/nwis/nwis

Publishing support provided by

Lafayette Publishing Service Center

Information regarding water resources in Texas is available at http://tx.usgs.gov/ 
